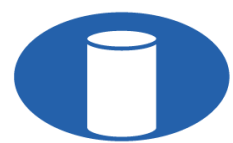

IBRACON

\title{
Assessment of design codes for the in-service behaviour of steel-concrete composite slabs
}

\author{
Avaliação dos códigos de projeto para o comportamento em serviço de lajes mistas \\ de aço-concreto
}

Lucas Antônio Morais Oliveira ${ }^{\mathrm{a}}$ (D)

Tainá Mascarenhas Borghi ${ }^{\mathrm{a}}$ (iD)

Yury Ouriques Rodrigues ${ }^{\mathrm{a}}$

Ana Lucia Homce de Cresce El Debs ${ }^{\mathrm{a}}$ (D)

${ }^{a}$ Universidade de São Paulo - USP, Escola de Engenharia de São Carlos, Departamento de Engenharia de Estruturas, São Carlos, SP, Brasil

Received 01 November 2020

Accepted 17 January 2021

\begin{abstract}
Steel-concrete composite slabs, also known as steel decking floor slabs or popularly as steel decks ${ }^{\circledR}$ have recent development and are advancing in Brazilian construction. There are relatively few researches about the long-term effects on composite slabs, and it has been identified that they can be significant in the evolution of deflections, mainly due to the effects of non-uniform shrinkage. However, there are no Brazilian references on the subject and Brazilian Code ABNT NBR 8800:2008 does not indicate any procedure for its evaluation. This paper presents a study on the serviceability limit state of excessive deflection with the application of two simplified approaches: Eurocode 4:2004 (European code) and AS/NZS 2327:2017 (Australian code), also comparing them against experimental results by the authors and literature. Due to the impermeability of the soffit face promoted by the steel decking, the occurrence of non-uniform shrinkage is a relevant aspect. As a consequence, the deflections were underestimated by Eurocode 4 . At the same time, the simplified approach of AS/NZS 2327, which explicitly takes into account the non-uniform shrinkage, presented good accuracy when compared to the experimental values. Finally, authors indicate the use of more robust prediction models for the evaluation of deflections in composite floors.
\end{abstract}

Keywords: composite structures, profiled steel decking, instantaneous and long-term deflections, creep and non-uniform shrinkage, cracking concrete.

Resumo: As lajes mistas, também chamadas de lajes com fôrma de aço incorporada e popularmente como steel deck ${ }^{\circledR}$, apresentam desenvolvimento relativamente recente no Brasil e têm ganhado espaço na construção civil. Existem poucas pesquisas sobre os efeitos diferidos no tempo em lajes mistas e têm-se identificado que estes podem ser significativos na evolução das flechas, sobretudo devido aos efeitos da retração não-uniforme. No entanto, não há referências nacionais e a ABNT NBR 8800:2008 não indica qualquer consideração de análise estrutural na sua avaliação. O presente trabalho apresenta um estudo sobre esse estado limite de serviço, com aplicação e comparação de duas abordagens de avaliação simplificadas: Eurocode 4:2004 e AS/NZS 2327:2017, comparando-as ainda com resultados experimentais dos autores e da literatura. Reforça-se que devido à impermeabilidade da face inferior promovida pela fôrma de aço, a ocorrência da retração não-uniforme é um aspecto relevante. Como resultado, a previsão das flechas foi subestimada no modelo Eurocode 4, quando comparado com a abordagem da AS/NZS 2327. Os resultados mostram que a abordagem simplificada da AS/NZS 2327, que leva em conta explicitamente a ocorrência da retração não-uniforme, apresentou boa acurácia quando comparada com os valores experimentais. Dessa forma, indica-se o uso de modelos de previsão mais robustos na avaliação das flechas desse sistema de pisos.

Palavras-chave: estruturas mistas, fôrma de aço incorporada, flechas imediatas e diferidas no tempo, fluência e retração não-uniforme, fissuração do concreto.

Corresponding author: Lucas Antônio Morais Oliveira. E-mail: lucasantonio12@usp.br

Financial support: Coordenação de Aperfeiçoamento de Pessoal de Nível Superior - Brasil (CAPES) - Finance Code 001 and (Grant number 2019/03513-5) - São Paulo Research Foundation (FAPESP).

Conflict of interest: Nothing to declare. 
How to cite: L. A. M. Oliveira. T. M. Borghi, Y. O. Rodrigues, and A. L. H. C. Debs, "Assessment of design codes for the in-service behaviour of steel-concrete composite slabs”, IBRACON Struct. Mater. J., vol. 14, no. 5, e14501, 2021, https://doi.org/10.1590/S1983-41952021000500001

\section{INTRODUCTION}

Steel-concrete slabs are composed of a steel sheeting and concrete filling and take advantage of the best characteristics of both materials. Lightness of steel profile and its high tensile strength are added to the excellent compression strength of concrete, relatively inexpensive material with low-maintenance, robustness and fire resistance. In this way, construction favors economy, speed, flexibility, high quality, sustainability and aesthetics. The use of composite slabs as a structural solution is promising and increasingly advantageous, being highlighted here some applications of this system in Brazil, as illustrated in Figure 1.
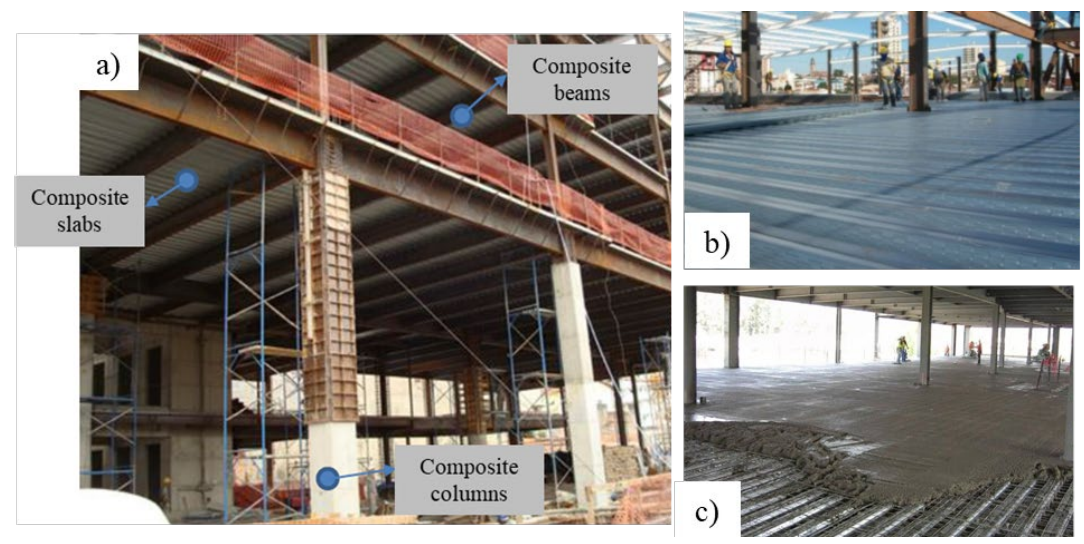

Figure 1. Steel-concrete composite structures: solution in composite floors. a) Composite structures in Real Hospital Português, Pernambuco (Brazil) [1]. b) Steel decking installation and c) Casting of slab concrete [2]

The composite behaviour is achieved when profiled steel sheeting is capable of transferring the longitudinal shear at the interface between steel and the concrete. The natural adhesion between steel and concrete is not sufficient to guarantee the composite behaviour, so mechanical and friction bonding mechanisms are also included. It is emphasised that the critical failure mode for composite slabs is commonly the longitudinal shear, characterising as partial interaction between components.

The structure should be attending all the ultimate limit states (ULS), both at normal- and under fire-situation. Altogether, the composite slabs must also attend the serviceability limit states (SLS) of excessive deflection, cracking and vibrations.

Given the slenderness of the composite floors, the excessive deflections are usually the primary check for the inservice conditions. Abdullah [3] points out that bending failure is not a dominant design criterion, because the interaction between steel and concrete is generally incomplete and the serviceability state of excessive deflections commonly limits the span of the slab.

The exact calculation of the deflection is highly complex due to the interdependence of the numerous variables and uncertainties involved. In this way, proposals for simplified methods for the deflection evaluation are presented by normative codes, being addressed here the approaches of Eurocode 4:2004 [4] and AS/NZS 2327:2017 [5] (Australian Standard / New Zealand Standard).

Recent researches on time-dependent deflections of composite slabs have been carried out. Some of the findings have been incorporated into the AS/NZS 2327 [5]. Must be advertised the contributions of Ranzi et al. [6] [7], Gholamhoseini [8] [9], Al-deen et al. [10].

This paper presents the results of an exploratory experimental program developed in Brazil, evaluating long-term deflections for a simply-supported steel-concrete composite slab under in- service conditions. Since Brazilian code ABNT NBR 8800:2008 [11] does not indicate any procedure for this calculation, the approaches of Eurocode 4 (EC4) and AS/NZS 2327 are presented and discussed. The procedures are used to predict the deflection and compared to the experimental result. 


\section{BEHAVIOUR OF STEEL-CONCRETE COMPOSITE SLABS}

The use of profiled steel decking, usually cold-formed profiles, has special functions: at first, they serve as formwork for the slab, supporting the loads during concrete casting and also act as a work platform. During the composite phase, they act as the positive reinforcement (part or total), play the role of horizontal diaphragm, distribute the deformations due to shrinkage and avoid excessive concrete cracking. Steel sheeting has advantages such as lightness when handled and installed, the possibility of dispensing shoring for the slab besides ease passage of ducts and installations. Finally, the system results in high speed of construction and waste reduction.

Figure 2 shows the scheme of the profiled sheeting types used in composite slabs. Usually, in trapezoidal forms (a) the mechanical connection is obtained employing mosses. In re-entrant forms (b) and clip-pan or L (c) form, the friction connection occurs due to the microscopic irregularities of the surface-associated to normal pressures (concrete confinement), with possible use of dents on the surface. In Brazil, the steel decking found on the market is the trapezoidal type.

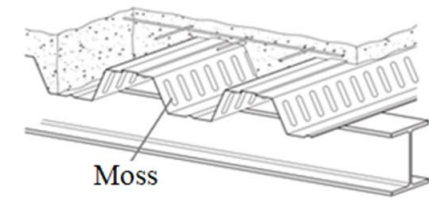

a) Trapezoidal type

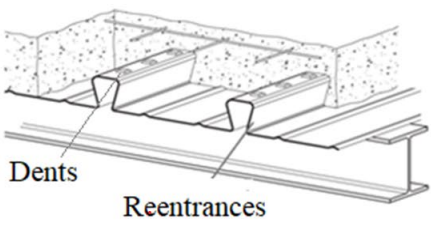

b) Re-entrant type

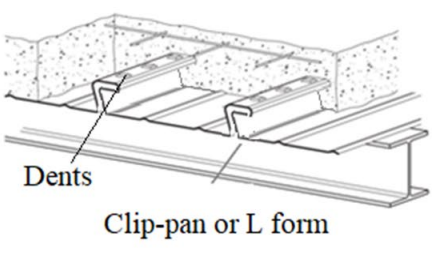

c) Clip-pan ou L type

Figure 2. Steel decking types for composite slabs

The main trapezoidal profiles available in Brazil have ribs between 45 to $75 \mathrm{~mm}$ of height, and they can be a competitive solution for spans from 2 to 4 meters, using secondary beams. In this condition, it is common to dispense shoring and, consequently, obtaining good agility in the construction. This system can be used in residential and commercial buildings, hospitals, schools, garages, bridges and industrial buildings.

Usually, manufacturers of the steel decking provide tables for the design of each profile and steel thickness. There one can find the maximum span without shoring for single, double and triple spans or structural balances, for each total height of slab. In general, for a given span, total thickness and height of the slab is defined, with the maximum load capacity

Present paper has focused on evaluating the in-service behaviour of composite slabs. However, the design of the slab is based on the resistance to the various ultimate limit states, headlining the longitudinal shear and, only later, on the verification of the in-service deflection.

Based on the knowledge of the concrete structures and for the understanding of the total deflections, it is vital to mention its division in two parts: the instantaneous deflection and time-dependent deflection. The first occurs as an accommodation due to the deformation of the materials. The second arises over time, under the action of long-term loads (concrete creep) and the concrete shrinkage. Furthermore, the cracking of the concrete changes the deformation profile of the sections, reduces their rigidity and contributes to the increase of deflection.

The exact deflection calculation depends on numerous variables, being very complex and turning impossible its use in routine design. Temperature and humidity, curing conditions and slab exposure condition, age of the concrete, loading history, compression reinforcement rate, dead load and live loads, among others, can affect the results, such as the uncertainties involved in the models of evaluation of creep and shrinkage concrete.

An important fact is the occurrence of non-uniform shrinkage of concrete due to the impermeability of the soffit slab, given the presence of the steel decking (seen in Figure 1 and 2). In this regard, underline the studies by Bradford et al. [12], Gilbert et al. [13]; Ranzi et al. [6]; Gilbert [14], Al-deen and Ranzi [15], Al-deen et al. [10] and Gholamhoseini [8] [9].

The phenomenon of non-uniform shrinkage significantly influences the evolution of time-dependent deflection and requires new analysis procedures, as highlighted by Gholamhoseini [8] [9]. Ranzi [16] proposed a simplified methodology for the assessment of in-service behaviour of steel-concrete slabs, already incorporated by the Australian code AS/NZS 2327 [5].

All experimental programs on the evaluation of the in-service deflection found [8]-[10] the occurrence of total interaction between steel and concrete, with no significant relative slips between the materials. The application of usual 
homogenisation on the cross-section proved to be coherent for the evaluation of the deflection, giving very accurate results. Furthermore, the more important factor affecting the predictions was the adoption of a non-uniform shrinkage profile. If the behaviour with partial interaction may occur due to variability of profiles steel decking in the global market, the basic article by Bradford [17] is indicated, which presents an analytical formulation with consideration of the time-dependents effects of concrete and partial interaction.

\section{DEFLECTION BY SIMPLIFIED APPROACHES}

The in-service behaviour of composite slabs is usually calculated by the classical method, with adaptations of the Euler-Bernoulli beam hypotheses and elastic-linear constitutive law. The equations consider the static balance, compatibility of deformations and constitutive laws of the materials. Limitation of the concrete stress values at most $40 \%$ of the compressive strength of concrete [18]. It uses the section homogenisation procedure for the structure with steel-concrete composite cross-section.

Total interaction is assumed with no occurrence of relative slips between steel and concrete. It was the typical situation presented under service condition as observed in the results of the experimental tests. The guidelines for deflection prediction in composite steel-concrete slabs are presented from the point of view of the Eurocode 4 [4] approaches and the Australian model AS/NZS 2327 [5].

\subsection{Deflection by Eurocode 4:2004 calculation}

Eurocode 4 [4] approach is the main one for deflection checking in technical manuals and books, as Johnson [19] and Dujmovic, Andrioic and Lukavevic [20]. Although the method does not explain the shrinkage effects, it indicates neglecting shrinkage effects in its clause EC4 [4] 9.8.2(3). The deflection under service conditions due to loading must be calculated using elastic and kinematic Euler-Bernoulli analysis with the following hypotheses:

- The longitudinal deformations of concrete and steel in any cross-section of the steel form are proportional to the distance of the neutral line fibre of the composite section. Plane sections remain plane after flexural bending;

- The stresses are proportional to the deformations in both concrete and steel;

- The entire steel cross-section must be used, except when reduced by holes;

- Usually, a reduced elasticity modulus is used for the consideration of concrete creep;

- The second moment of area used in the deflection calculations must be considered as the average of the uncracked and cracked concrete in the composite section.

EC4 [4] presents the evaluation of the effect of creep deformation, adopting the simplified procedure as presented for the composite beams, dividing the modulus of elasticity of the concrete by 2 in Equation 1 (Eurocode 4:2004). As a comparison, the British Standard BS 5950: 1994 [21] (replaced by EC4) indicates for the calculation a consideration of a weighted average for both short- and long-term effects, according to Equation 2 (BS 5950:1994).

$\mathrm{E}_{\mathrm{cm}}^{\prime}=\frac{1}{2} \cdot \mathrm{E}_{\mathrm{cm}}$

$\mathrm{E}_{\mathrm{cm}}^{\prime}=\frac{1}{2} \cdot\left(\mathrm{E}_{\mathrm{cm}}+\frac{\mathrm{E}_{\mathrm{cm}}}{3}\right)=\frac{2}{3} \cdot \mathrm{E}_{\mathrm{cm}}$

Regarding the second moment of area of the concrete in the steel-concrete composite section, the average presented by the cracked section $\left(I_{c r}\right)$ and uncracked section $\left(I_{\text {uncr }}\right)$ is adopted, to take into account the occurrence of concrete cracking, according to Equation 3.

$I_{m}=\frac{I_{\text {uncr }}+I_{\text {cr }}}{2}$

The predicted deflection $(\delta)$ for a composite slab simply-supported under uniformly distributed loading $\left(\mathrm{p}_{\text {tot }}\right)$, unidirectional span (l), steel decking elastic modulus $\left(\mathrm{E}_{S d}\right)$ and with section homogenisation $\left(\mathrm{I}_{\mathrm{m}}\right)$ based on the steel profile is given by Equation 4 . 
$\delta=\frac{5}{384} \cdot \frac{\mathrm{p}_{\text {tot }} \cdot 1^{4}}{\mathrm{E}_{\mathrm{Sd}} \cdot \mathrm{I}_{\mathrm{m}}}$

For composite slabs calculated with continuity on intermediate supports, the expressions can be taken based on the elastic-line in the deflection evaluation.

\subsection{Deflection by AS/NZS 2327:2017 simplified calculation}

Proposed in the last update of the Australian Standard AS/NZS 2327 [5] is presented in more detail in Al-deen and Ranzi [15] and Ranzi [16]. It takes into account more explicitly the factors that affect the time-dependent behaviour. The model incorporates the contribution of cracked concrete stiffness, the portions due to creep and non-uniform shrinkage in deflection calculations. Also, it uses elastic and kinematic Euler-Bernoulli analysis.

The code indicates that the procedure applies to the design of composite slabs when the effects of relative slips are considered insignificant. If not attended, end anchorages must be provided; alternatively, the deflection calculations must include these effects.

The deflection due to the loading applied only on the steel formwork must be calculated, taking into account its self-weight and the weight of fresh concrete. Special attention must be given to the occurrence of ponding effects when considering or not increasing the self-weight when not temporary shoring was used. In the composite phase, the instantaneous deflections are calculated after curing due to their self-weight, when removing shoring, if existing, and applying imposed loads.

Total deflection $\left(\delta_{\text {tot }}\right)$ is given by the sum of the instantaneous and time-dependent deflection caused by the permanent loads and the variables loads, effects of creep and shrinkage, given by Equation 5. Figure 3 schematically illustrates the concrete structures deflections plots.

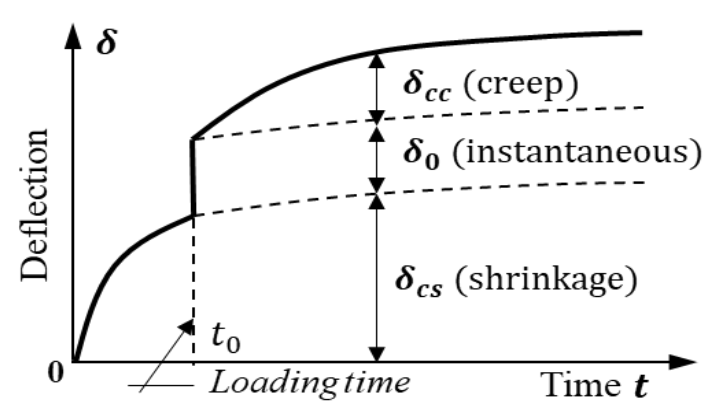

Figure 3. Concrete structures deflections plots

$\delta_{\text {tot }}=\delta_{0}+\delta_{\mathrm{cc}}+\delta_{\mathrm{cs}}$

where:

$\delta_{0}=$ instantaneous deflection; $\delta_{\mathrm{cc}}=$ creep deflection; $\delta_{\mathrm{cs}}=$ shrinkage deflection

The guide for the definition and deflection calculation are presented, taking as the theoretical reference of Ranzi [16] and AS/NZS 2327 [5].

\subsubsection{Instantaneous deflection}

The instantaneous deflection $\left(\delta_{0}\right)$ that occurs when applying external loads must be calculated using the value of $E_{c}$ (concrete elasticity module determined at the moment considered) and the value of the second moment of area $\left(I_{e f}\right.$ ) in expression of the maximum deflection by elastic line, usually evaluated at mid-span. The material properties for concrete must be those corresponding to the age of the composite slab when external loads are applied for the first time. Simplified process for calculating the value of $\mathrm{I}_{\mathrm{ef}}$ can be used and must be determined from the values of the position of the cross-sections: 
(a) For a simply supported slab, the value at midspan;

(b) In a composite slab with continuity on intermediate supports:

(i) for an interior span, half the midspan value plus one-quarter of each support value;

(ii) for end span, half the midspan value plus half the value at the continuous support;

(c) For a cantilever, the value at the support.

The effective inertia value $I_{e f}$ in each of the indicated cross-section is given (Equation 6).

$I_{\text {ef }}=I_{\text {cr }}+\left(I_{\text {uncr }}-I_{\text {cr }}\right) \cdot\left(\frac{M_{\text {cr }}}{M_{s}}\right)^{3} \leq I_{\text {ef }, \text { max }}$

where:

$\mathbf{I}_{\mathbf{e f}, \max }=$ maximum effective second moment of area and equal to $\mathrm{I}_{\mathrm{uncr}}$;

$\mathbf{I}_{\mathbf{c r}}=$ second moment of area of the cracked section (disregarding the contribution of the tensile concrete) and with the steel reinforcement and steel decking homogenised in an equivalent concrete;

$\mathbf{I}_{\mathbf{u n c r}}=$ second moment of area of the uncracked section and with the reinforcement and steel decking transformed into an equivalent concrete area;

$\mathbf{M}_{\mathbf{s}}=$ maximum moment in-service;

$\mathbf{M}_{\mathbf{c r}}=$ cracking moment, given by (Equation 7).

A highlight is the consideration of the tensile stress caused by the shrinkage in the calculation of the cracking moment. Given the existence of the profiled steel decking, it ends up preventing the free deformation of the concrete, resulting in tensions. The tensile stress resulting from the shrinkage $\left(\sigma_{\mathrm{cs}}\right)$ decreases the flexural tensile strength of the concrete $\left(\mathrm{f}_{\mathrm{ct}, \mathrm{f}}\right)$.

The methodology presented by Gilbert and Ranzi [18] was taken as a basis for analysing the cross-sections composed of steel and concrete. According to Ranzi [16], the cracking moment evaluation can be rewritten based on the properties of the composite section and presented in its general form, according to Equations 7-8.

$$
\mathrm{M}_{\mathrm{cr}}=\frac{1}{\mathrm{E}_{\mathrm{c}} \cdot\left(\frac{\mathrm{R}_{\mathrm{B}}}{\mathrm{R}_{0}}-\mathrm{y} \cdot \frac{\mathrm{R}_{\mathrm{A}}}{\mathrm{R}_{0}}\right)} \cdot\left(\mathrm{f}_{\mathrm{ct}, \mathrm{f}}-\sigma_{\mathrm{cs}}\right) \geq 0
$$

Where: $\mathrm{R}_{0}=\mathrm{R}_{\mathrm{I}} \cdot \mathrm{R}_{\mathrm{A}}-\mathrm{R}_{\mathrm{B}}^{2}$

The parcels $R_{A, 0}, R_{B, 0}$ and $R_{I, 0}$ represent the axial stiffness, the static moment and the flexural moment, at time $\mathrm{t}_{0}$ without considering time-dependent effects of concrete, given by Equations 9-10-11, respectively. This methodology aims to homogenize the composite section and allows adequate programming in electronic spreadsheets. The terms are calculated with the reference axis at bottom of the slab, defined as seen in Figure 4.

$$
\begin{aligned}
& \mathrm{R}_{\mathrm{A}, 0}=\sum_{\mathrm{i}=1}^{\mathrm{m}_{\mathrm{c}}} \mathrm{A}_{\mathrm{c}(\mathrm{i})} \cdot \mathrm{E}_{\mathrm{c}(\mathrm{i}), 0}+\sum_{\mathrm{i}=1}^{\mathrm{m}_{\mathrm{s}}} \mathrm{A}_{\mathrm{s}(\mathrm{i})} \cdot \mathrm{E}_{\mathrm{s}(\mathrm{i})}+\mathrm{A}_{\mathrm{sd}} \cdot \mathrm{E}_{\mathrm{sd}}=\mathrm{R}_{\mathrm{A}, \mathrm{c}}+\mathrm{R}_{\mathrm{A}, \mathrm{s}}+\mathrm{R}_{\mathrm{A}, \mathrm{sd}} \\
& \mathrm{R}_{\mathrm{B}, 0}=\sum_{\mathrm{i}=1}^{\mathrm{m}_{\mathrm{c}}} \mathrm{B}_{\mathrm{c}(\mathrm{i})} \cdot \mathrm{E}_{\mathrm{c}(\mathrm{i}), 0}+\sum_{\mathrm{i}=1}^{\mathrm{m}_{\mathrm{s}}} \mathrm{y}_{\mathrm{s}(\mathrm{i})} \cdot \mathrm{A}_{\mathrm{s}(\mathrm{i})} \cdot \mathrm{E}_{\mathrm{s}(\mathrm{i})}+\mathrm{B}_{\mathrm{sd}} \cdot \mathrm{E}_{\mathrm{sd}}=\mathrm{R}_{\mathrm{B}, \mathrm{c}}+\mathrm{R}_{\mathrm{B}, \mathrm{s}}+\mathrm{R}_{\mathrm{B}, \mathrm{sd}} \\
& \mathrm{R}_{\mathrm{I}, 0}=\sum_{\mathrm{i}=1}^{\mathrm{m}_{\mathrm{c}}} \mathrm{I}_{\mathrm{c}(\mathrm{i})} \cdot \mathrm{E}_{\mathrm{c}(\mathrm{i}), 0}+\sum_{\mathrm{i}=1}^{\mathrm{m}_{\mathrm{s}}} \mathrm{y}_{\mathrm{s}}^{2} \cdot \mathrm{A}_{\mathrm{s}(\mathrm{i})} \cdot \mathrm{E}_{\mathrm{s}(\mathrm{i})}+\mathrm{I}_{\mathrm{sd}} \cdot \mathrm{E}_{\mathrm{sd}}=\mathrm{R}_{\mathrm{I}, \mathrm{c}}+\mathrm{R}_{\mathrm{I}, \mathrm{s}}+\mathrm{R}_{\mathrm{I}, \mathrm{sd}}
\end{aligned}
$$

where: 
$\boldsymbol{R}_{\boldsymbol{A}}=$ axial stiffness calculated at time $\mathrm{t}_{0}$ in uncracked condition;

$\boldsymbol{R}_{B}=$ stiffness associated with the first area moment at time $\mathrm{t}_{0}$ in uncracked condition;

$\boldsymbol{R}_{\boldsymbol{I}}=$ flexural stiffness calculated at time $\mathrm{t}_{0}$ in uncracked condition.

The subscriptions "c", "sd", "s" references the following components: concrete, steel decking and, steel reinforcement, respectively:

$\mathbf{E}=$ elastic modulus;

$\mathbf{A}=$ cross-sectional area of the material;

$\mathbf{B}=$ first area moment (static moment);

$\mathbf{I}=$ second moment of area of the section;

$\mathbf{y}_{i}=$ position of the vertical axis of the steel bars (reinforcement).

The maximum tensile stress induced by shrinkage $\left(\sigma_{\mathrm{cs}}\right)$ in the outer fibre in which the crack occurs, can be calculated by Equations 12-13.

$\sigma_{c s}=\frac{E_{e f, c s}}{R_{I, c s} \cdot R_{A, c s}-R_{B, c s}^{2}} \cdot\left[\left(R_{I, c s}-y \cdot R_{B, c s}\right) \cdot f_{c s 1}+\left(R_{B, c s}-y \cdot R_{A, c s}\right) \cdot f_{c s 2}\right]-E_{e f, c s} \cdot\left(\varepsilon_{r, c s}-y \cdot \kappa_{c s}\right)$

$\left[\begin{array}{l}f_{\text {cs } 1} \\ f_{c s 2}\end{array}\right]=E_{e f, c s} \cdot\left[\begin{array}{c}A_{c} \cdot \varepsilon_{r, c s}-B_{c} \cdot \kappa_{r, c s} \\ -B_{c} \cdot \varepsilon_{r, c s}+I_{c} \cdot \kappa_{r, c s}\end{array}\right]$

where:

$\mathbf{A}_{\mathbf{c}}=$ area of the concrete section;

$\mathbf{B}_{\mathbf{c}}=$ first moment area of the concrete;

$\mathbf{I}_{\mathbf{c}}=$ second moment area of concrete;

$\mathbf{R}_{\mathbf{A}, \mathrm{cs}}=$ axial stiffness at time $\mathrm{t}_{0}$ for uncracked section, using effective module $\mathrm{E}_{\mathrm{ef}, \mathrm{cs}}$;

$\mathbf{R}_{\mathbf{B}, \mathrm{cs}}=$ stiffness associated with the static moment of area at time $\mathrm{t}_{0}$ for uncracked section, using effective module $\mathrm{E}_{\mathrm{ef}, \mathrm{cs}}$;

$\boldsymbol{R}_{I, c s}=$ flexural stiffness at time $\mathrm{t}_{0}$ for uncracked section, using effective module $\mathrm{E}_{\mathrm{ef}, \mathrm{cs}}$;

$\varepsilon_{\mathrm{r}, \mathrm{ss}}=$ shrinkage deformation at the adopted reference level that defines the non-uniform shrinkage distribution;

$\boldsymbol{\kappa}_{\mathrm{r}, \mathrm{es}}=$ curvature that defines the non-uniform concrete shrinkage distribution.

\subsubsection{Creep deflection}

The creep deflection component $\left(\delta_{\mathrm{cc}}\right)$ is determined by multiplying the instantaneous deflection produced by loading $\left(\delta_{0, \mathrm{i}}\right)$ by the creep multiplier $\left(\alpha_{\mathrm{cc}}\right)$, given in Equations $14-15$.

$\boldsymbol{\delta}_{c c}=\boldsymbol{\delta}_{0, \mathrm{i}} \cdot \boldsymbol{\alpha}_{\mathrm{cc}}$

$\alpha_{\mathrm{cc}}=\frac{\mathrm{E}_{\mathrm{c}} \mathrm{I}_{\mathrm{ef}}}{\mathrm{E}_{\mathrm{ef}, \mathrm{cc}} \mathrm{I}_{\mathrm{ef}, \mathrm{cc}}}-1$

where:

$\boldsymbol{E}_{\boldsymbol{c}}=$ value of the static module of concrete at the time of the first loading (or calculated at 28 days if the time of the first loading is not known or expects to be greater than 28 days).

The modulus $\mathrm{E}_{\mathrm{ef}, \mathrm{cc}}$ is given by Equation 16.

$$
\mathrm{E}_{\mathrm{ef}, \mathrm{cc}}=\frac{\mathrm{E}_{\mathrm{c}}}{1+\varphi_{\mathrm{cc}}}
$$


$\boldsymbol{\varphi}_{\mathbf{c c}}=$ creep coefficient calculated for the concrete at the time of interest for the first loading at time $\mathrm{t}_{0}$, considering the following conditions when calculating the hypothetical thickness $t_{h}=2 A_{g} / u_{e}$. It can be calculated according to the normative codes for structural concrete.

(a) $\mathbf{A}_{\mathbf{g}}$ it was assumed equal to the cross-sectional area of the composite slab, therefore, using the actual thickness of the composite slab in the calculation of $\mathrm{A}_{\mathrm{g}}$;

(b) $\mathbf{u}_{\mathrm{e}}$ it is taken equal to the width of the slab (assuming, therefore, that concrete drying occurs only from the exposed surface of the slab). For the calculations, the properties for unit width were considered.

$\mathbf{I}_{\mathrm{ef}}=$ effective second moment of area calculated with Equation 6 using $\mathrm{E}_{\mathrm{ef}, \mathrm{cc}}$ for the concrete static module, for the age evaluated;

$\mathbf{I}_{\mathbf{e f}, \mathbf{c c}}=$ second moment of area calculated according to Equation 6 using $\mathrm{E}_{\mathrm{ef}, \mathrm{cc}}$ for the concrete static modulus for time $\mathrm{t}_{0}$. According to Ranzi [16], it can be assumed that the cracked concrete section corresponds to that identified at time $\mathrm{t}_{0}$ for instantaneous deflection calculation.

The AS/NZS 2327 [5] code still indicates that when $\mathbf{I}_{\mathbf{e f}, \mathbf{c c}}$ is evaluated, the second moment of area associated with the cracked section can be determined based on the cracked geometry identified for the short-term tests.

\subsubsection{Shrinkage deflection}

The non-uniform shrinkage profile is due to the presence of the steel decking, which turns the underside impermeable. The linear gradient adopted is an approximation of the real gradient, introduced to simplify the calculations. The conditions specified for the hypothetical thickness are based on the fact that the shrinkage gradient was calibrated based on shrinkage profiles induced by concrete slabs exposed on both sides with the same slab's thickness.

In the simplified method, the shrinkage profile used in the induced deflection calculation due to the shrinkage and cracking moment can be based on a linear gradient shrinkage distribution with deformation of $\eta_{b, k}=0,2 \varepsilon_{\mathrm{cs}}$ on the bottom face of the slab and $\eta_{t, k}=1,2 \varepsilon_{\mathrm{cs}}$ on the top face slab (exposed surface). Which $\varepsilon_{\mathrm{cs}}$ is the concrete shrinkage strain. Figure 4 shows the reference for deformation and curvature shrinkage.

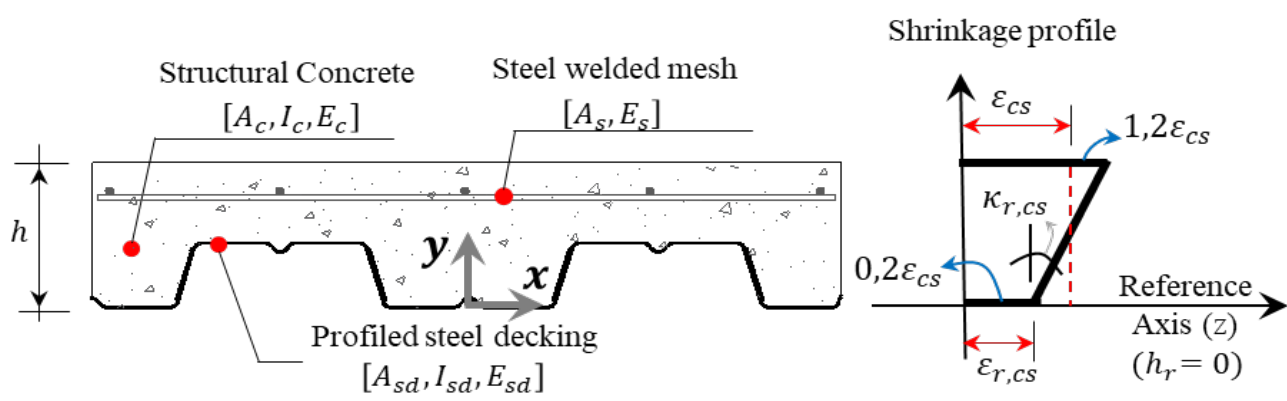

Figure 4. Linear shrinkage gradient and reference axis system.

$\varepsilon_{\mathrm{r}, \mathrm{cs}}=\frac{\left(\mathrm{h}-\mathrm{h}_{\mathrm{r}}\right) \cdot \eta_{\mathrm{t}, \mathrm{k}}+\mathrm{h}_{\mathrm{r}} \cdot \eta_{\mathrm{b}, \mathrm{k}}}{\mathrm{h}} \cdot \varepsilon_{\mathrm{cs}, \mathrm{k}}$

$\kappa_{\mathrm{r}, \mathrm{cs}}=\frac{\left(\eta_{\mathrm{t}, \mathrm{k}}-\eta_{\mathrm{b}, \mathrm{k}}\right)}{\mathrm{h}} \cdot \varepsilon_{\mathrm{cs}, \mathrm{k}}$

The reference strain value $\varepsilon_{\mathrm{cs}}$ can be calculated according to the normative codes for structural concrete and adopts a hypothetical thickness equal to the thickness of the slab. The linearly varied non-uniform profile can be given by the reference strain $\varepsilon_{\mathrm{r}, \mathrm{cs}}$ (Equation 17) and by the curvature given by the ratio of the difference between deformation on the top and bottom face by the height of the slab section (Equation 18). 
For simply-supported slab, schematically shown in Figure 5, due to the restriction of the free shrinkage by the steel decking, appearance of normal eccentric stress, an internal moment is generated due to the $\mathrm{M}_{\mathrm{cs}}$. The shrinkage deflection can be expressed by the curvature $(\kappa)$ given that are directly proportional to flexural moment $(M(z)=\kappa E I)$. The component $\delta_{\mathrm{cs}}$ is calculated using the curvature and its span $(l)$ by Equation 19.

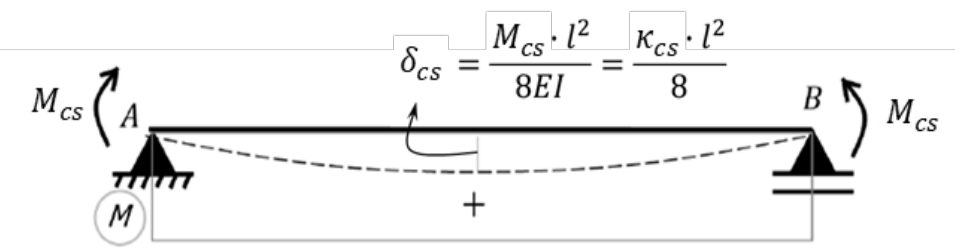

Figure 5. Simply-supported beam model with moments at the ends

$\delta_{\mathrm{cs}}=\frac{\kappa_{\mathrm{cs}} \cdot \mathrm{L}^{2}}{8}$

The shrinkage deflection component $\left(\delta_{\mathrm{cs}}\right)$ must be determined for long-term analysis, considering the effects expressed by the shrinkage curvature induced, according to Equations 20-21, respectively.

$\kappa_{\mathrm{cs}}=\left(1-\gamma_{\mathrm{cs}}\right) \cdot \kappa_{\mathrm{cs}, \mathrm{cr}}+\gamma_{\mathrm{cs}} \cdot \kappa_{\mathrm{cs}, \text { uncr }}$

$\gamma_{\mathrm{cs}}=\left(\frac{\mathrm{M}_{\mathrm{cr}}}{\mathrm{M}_{\mathrm{s}}}\right)^{2} \leq 1$

where:

$\kappa_{\mathrm{cs}, \text { uncr }}=$ shrinkage curvature for an uncracked cross-section considering the effective modulus of elasticity $\mathrm{E}_{\mathrm{ef}, \mathrm{cs}}$ for the concrete;

$\kappa_{\mathrm{cs}, \mathrm{cr}}=$ shrinkage curvature for a cracked cross-section considering the effective modulus of elasticity $\mathrm{E}_{\mathrm{ef}, \mathrm{cs}}$ for the concrete.

$\mathrm{E}_{\mathrm{ef}, \mathrm{cs}}$ is given by Equation 22 .

$\mathrm{E}_{\mathrm{ef}, \mathrm{cs}}=\frac{\mathrm{E}_{\mathrm{c}}}{1+0,55 \cdot \varphi_{\mathrm{cc}}}$

The curvature $\kappa_{\mathrm{cs}}$ is determined based on the weighting of the effects of the cracked $\left(\kappa_{\mathrm{cs}, \mathrm{cr}}\right)$ and uncracked section $\left(\kappa_{\mathrm{cs}, u n c r}\right)$. They can be determined for the composite slab cross-section according to the procedure by Equations 23-24, respectively.

$$
\begin{aligned}
& \kappa_{\mathrm{cs}, \text { uncr }}=\left[\begin{array}{ll}
\frac{\mathrm{R}_{\mathrm{B}, \mathrm{cs} \text {,uncr }}}{\mathrm{R}_{0, \mathrm{cs} \text {,uncr }}} & \frac{\mathrm{R}_{\mathrm{A}, \mathrm{cs} \text {,uncr }}}{\mathrm{R}_{0, \mathrm{cs} \text {, uncr }}}
\end{array}\right] \cdot \mathrm{E}_{\mathrm{ef}, \mathrm{cs}} \cdot\left[\begin{array}{l}
\mathrm{A}_{\mathrm{c} \text {,uncr }} \cdot \varepsilon_{\mathrm{r}, \mathrm{cs}}-\mathrm{B}_{\mathrm{c} \text {,uncr }} \cdot \kappa_{\mathrm{r}, \mathrm{cs}} \\
-\mathrm{B}_{\mathrm{c}, \text { uncr }} \cdot \varepsilon_{\mathrm{r}, \mathrm{cs}}+\mathrm{I}_{\mathrm{c}, \text { uncr }} \cdot \kappa_{\mathrm{r}, \mathrm{cs}}
\end{array}\right] \\
& \kappa_{\mathrm{cs}, \mathrm{cr}}=\left[\begin{array}{ll}
\frac{\mathrm{R}_{\mathrm{B}, \mathrm{cs}, \mathrm{cr}}}{\mathrm{R}_{0, \mathrm{cs}, \mathrm{cr}}} & \mathrm{R}_{\mathrm{A}, \mathrm{cs}, \mathrm{cr}} \\
\mathrm{R}_{0, \mathrm{cs}, \mathrm{cr}}
\end{array}\right] \cdot \mathrm{E}_{\mathrm{ef}, \mathrm{cs}} \cdot\left[\begin{array}{l}
\mathrm{A}_{\mathrm{c}, \mathrm{cr}} \cdot \varepsilon_{\mathrm{r}, \mathrm{cs}}-\mathrm{B}_{\mathrm{c}, \mathrm{cr}} \cdot \kappa_{\mathrm{r}, \mathrm{cs}} \\
-\mathrm{B}_{\mathrm{c}, \mathrm{cr}} \cdot \varepsilon_{\mathrm{r}, \mathrm{cs}}+\mathrm{I}_{\mathrm{c}, \mathrm{cr}} \cdot \kappa_{\mathrm{r}, \mathrm{cs}}
\end{array}\right]
\end{aligned}
$$


The second moment of area of the sections can be obtained by the stiffness of the section from a reference axis, using Equations 25-26.

$I_{\text {uncr }}=\frac{R_{I} \cdot R_{A}-R_{B}^{2}}{R_{A} \cdot E_{c}}$

$\mathrm{I}_{\mathrm{cr}}=\frac{\mathrm{R}_{\mathrm{I}, \mathrm{cr}} \cdot \mathrm{R}_{\mathrm{A}, \mathrm{cr}}-\mathrm{R}_{\mathrm{B}, \mathrm{cr}}^{2}}{\mathrm{R}_{\mathrm{A}, \mathrm{cr}} \cdot \mathrm{E}_{\mathrm{c}}}$

where:

$\mathbf{I}_{\text {uncr }}=$ second moment of area of the homogenised uncracked section;

$\mathbf{I}_{\mathbf{c r}}=$ second moment of area of the homogenised cracked section;

$\mathbf{R}_{\mathbf{A}, \mathbf{c r}}=$ axial stiffness calculated at time $\mathrm{t}_{0}$ for cracked section;

$\mathbf{R}_{\mathbf{B}, \mathbf{c r}}=$ stiffness associated with the static moment of the area at time $t_{0}$ for cracked section;

$\mathbf{R}_{\mathbf{I}, \mathbf{c r}}=$ flexural stiffness at time $\mathrm{t}_{0}$ for cracked section.

Attention to the clear differences between the two simplified approaches for the deflection calculations. The Brazilian Standard NBR 8800:2008 [11] does not indicate a method for evaluating deflection in composite slabs. Usually, Eurocode 4 [4] is used. The detailed development of an example using the simplified method presented previously to evaluate the total deflection of the experimental test performed by the authors is presented. It is considered an infinite time of 10,000-days, in which, all the deformations due to the effects of concrete shrinkage and creep have occurred.

\section{EXPERIMENTAL DATA AND CHARACTERISTICS OF COMPOSITE SLABS}

The long-term experimental test with composite steel-concrete slab was developed at the São Carlos School of Engineering with a duration of 134 days. The composite slab consisted of steel decking profile MD55 [22] trapezoidal type with a nominal thickness of $0.80 \mathrm{~mm}$. Table 1 presents the properties of the profiled steel decking MD55, based on unit width and design thickness, disregarding the zinc layer protection thickness of $0.04 \mathrm{~mm}$. Figure 6 shows the composite slab cross-section.

Table 1. Properties of MD55 trapezoidal steel decking

\begin{tabular}{ccccc}
\hline $\begin{array}{c}\text { Profile Steel } \\
\text { Decking }\end{array}$ & $\begin{array}{c}\text { Thickness } \\
\left(\mathrm{t}_{\mathrm{sd}}\right)\end{array}$ & $\begin{array}{c}\text { Cross Section Area } \\
\left(\mathrm{A}_{\mathrm{sd}}\right)\end{array}$ & Centroid Height $\left(\mathrm{h}_{\mathrm{sd}}\right)$ & $\begin{array}{c}\text { Second moment of area } \\
\left(\mathrm{I}_{\mathrm{sd}}\right)\end{array}$ \\
\hline MD55 & $0.76 \mathrm{~mm}$ & $975 \mathrm{~mm}^{2} / \mathrm{m}$ & $27.5 \mathrm{~mm}$ & $565,550 \mathrm{~mm}^{4} / \mathrm{m}$ \\
\hline
\end{tabular}

The concrete was composed of natural aggregates of the basaltic gravel and river sand, and cement CPII-Z-32. The compressive strength was $\mathrm{f}_{\mathrm{cm}}=31.12 \mathrm{MPa}$, flexural tensile strength $\mathrm{f}_{\mathrm{ct.f}}=3.54 \mathrm{MPa}$ and elastic modulus $\mathrm{E}_{\mathrm{c}}=30.00$ $\mathrm{GPa}$, at 28 days. Used welded steel mesh with a $\phi 4.2 \mathrm{~mm} \mathrm{c} / 150 \mathrm{~mm}\left(92 \mathrm{~mm}^{2} / \mathrm{m}\right)$ at $30 \mathrm{~mm}$ from the top face. The steel decking presents an elastic modulus $\mathrm{E}_{\mathrm{Sd}}=204.00 \mathrm{GPa}$ and the steel welded mesh $\mathrm{E}_{\mathrm{s}}=191.00 \mathrm{GPa}$.

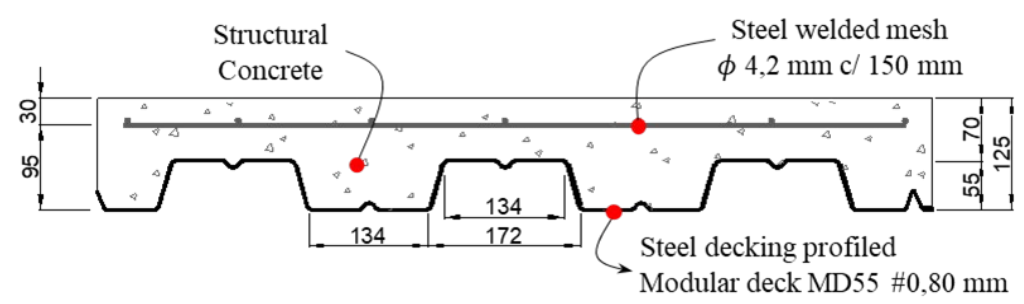

Figure 6. Cross-section of composite slabs (measured in $\mathrm{mm}$ ) 
The prototype of the composite slab had a total height of $125 \mathrm{~mm}$ and a total span of 3,200 $\mathrm{mm}$, with an effective span of $3,000 \mathrm{~mm}$. The structural system was under simply-supported condition. Figure $7 \mathrm{a}$ shows the static configuration and the in-service loading, consisting of two parts: the slab self-weight $\left(2.40 \mathrm{kN} / \mathrm{m}^{2}\right)$ and the imposed load $\left(2.26 \mathrm{kN} / \mathrm{m}^{2}\right)$. Figure $7 \mathrm{~b}$ shows the experimental test that consisted of loading distributed uniformly by concrete prisms on the slab. The slab had a 7-day wet curing process.

For the quasi-permanent load combination (long-term SLS), the imposed load represents a permanent load parcels due finishes and partitions $\left(1.06 \mathrm{kN} / \mathrm{m}^{2}\right)$ and long-term live load $\left(1.20 \mathrm{kN} / \mathrm{m}^{2}\right)$ due $\psi_{2} \cdot \mathrm{Q}_{\mathrm{k}}$, where partial factor load $\psi_{2}=0.30$ and live load $\mathrm{Q}_{\mathrm{k}}=4.00 \mathrm{kN} / \mathrm{m}^{2}$ (office areas).

The deflection measurements started at the age of 8-days after concrete casting, with the removal of the shoring placed in the mid-span. Dial gauges were arranged in the middle span. After removing the shoring, the measured instantaneous deflection due to self-weight was $0.35 \mathrm{~mm}$. At 28 days, deflection reached $2.00 \mathrm{~mm}$. On that same date, an imposed load was applied, simulating in-service loadings.
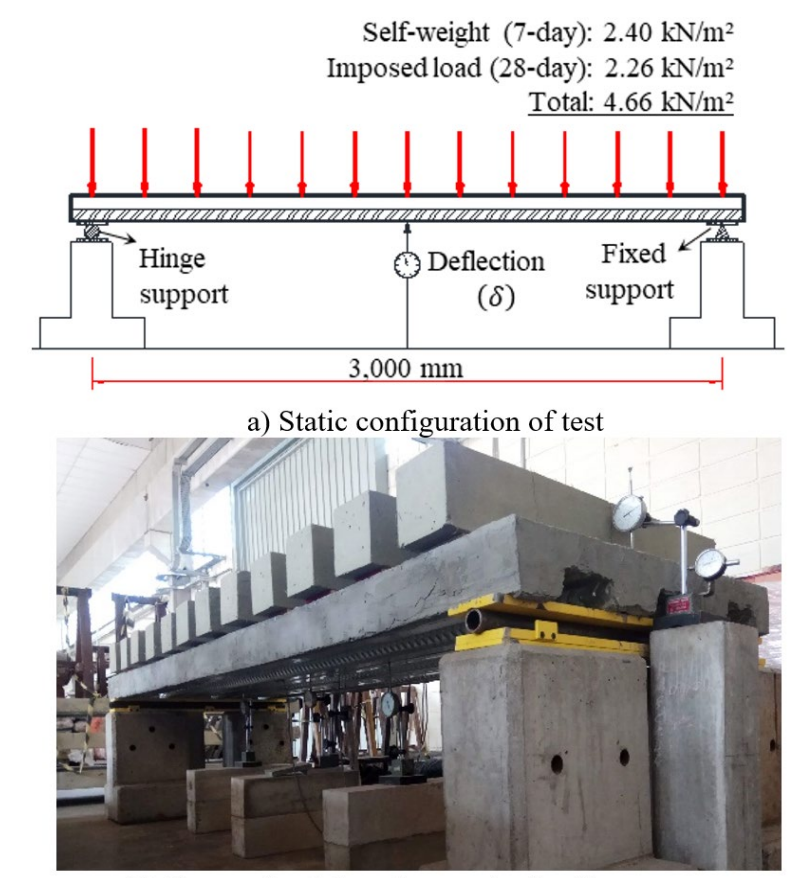

b) Composite slab under service loading

Figure 7. Long-term experimental test in composite slab

The instantaneous deflection resulting from the imposed loads was $0.65 \mathrm{~mm}$. The deflection at the end of the experiment was $4.47 \mathrm{~mm}$. The total instantaneous deflection was $1.00 \mathrm{~mm}$, while the time-dependent deflection was $3.47 \mathrm{~mm}$, at the age of 134 days.

The temperature and relative air humidity were monitored at the test site, with averages of $21.5^{\circ} \mathrm{C}$ and $58.2 \%$, respectively. The coefficients of variation were $10.7 \%$ and $18.8 \%$, respectively. It is essential to highlight the lateral sealing of the slabs with the use of waterproofing mortars in order to simulate the real situation regarding the drying process that influences the shrinkage phenomenon.

Visual inspections identified no cracks. The existence of dial gauges confirmed the absence of relative slips at the ends of the composite slab assessed for the in-service evaluation.

The deflections obtained for the tested composite slab were compared to the predictions given by EC4 [4] and AS/NZS 2327 [5] and a discussion on the accuracy of models is presented. 


\section{RESULTS OF THE DEFLECTION CALCULATIONS}

\subsection{Eurocode 4 approach}

Based on the characteristics and properties of the composite slab, a procedure for the deflection calculation is presented. Figure 8 presents the deflection $\left(\delta_{\text {tot }}\right)$ predicted by EC4 for the composite slab, seen Equation 4.

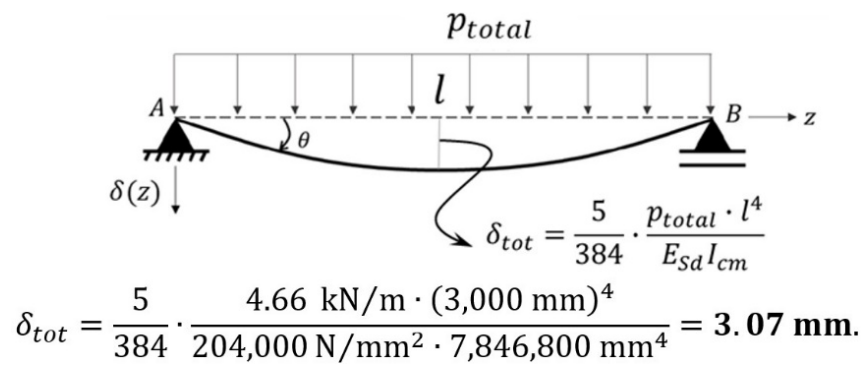

Figure 8. Static system of the simply-supported composite slab

In the expression, total load $\left(\mathrm{p}_{\mathrm{tot}}\right)$ considered self-weight plus imposed load, span was $3.000 \mathrm{~mm}$, and material properties were steel modulus properties $\left(\mathrm{E}_{\mathrm{Sd}}\right)$ and weighted average second moment of area $\left(\mathrm{I}_{\mathrm{m}}\right)$, whose calculation is showed below. The modular ratio $\mathrm{n}$ considered the long-term effects with reduced modulus according to Equation 27:

$\mathrm{n}=\frac{\mathrm{E}_{\mathrm{Sd}}}{\mathrm{E}_{\mathrm{c}}^{\prime}}=\frac{\mathrm{E}_{\mathrm{Sd}}}{0,5 \cdot \mathrm{E}_{\mathrm{c}}}=\frac{204,000}{0,5 \cdot 30,000}=13.6$

From the slab cross-section, an equivalent $\mathrm{T}$ section is adopted for unit width, schematically shown in Figure 9. The value of $b_{m}$ is given by Equation 28 .

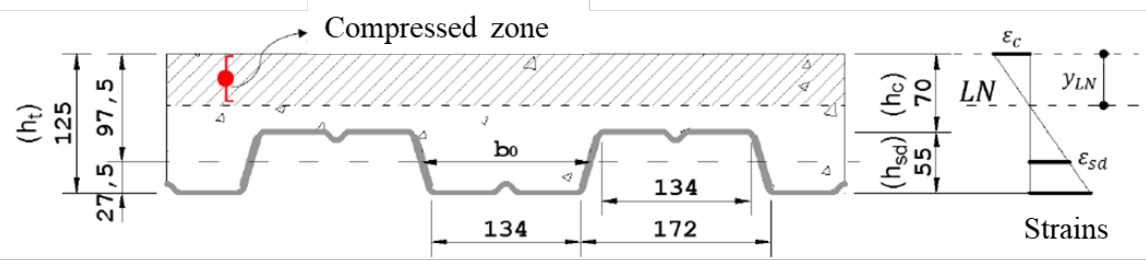

Figure 9. Composite slab slab variables and measures

$\mathrm{b}_{0}=\frac{172+134}{2}=153 \mathrm{~mm} \Rightarrow \mathrm{b}_{\mathrm{m}}=\frac{\mathrm{b}}{\mathrm{b}_{\mathrm{s}}} \cdot \mathrm{b}_{0}=\frac{1000}{306} \cdot 153=500 \mathrm{~mm} / \mathrm{m}$

Second moment of area of the uncracked section, $\mathrm{I}_{\text {uncr }}$, for unit width $\mathrm{b}$ (Equation 29).

$\mathrm{I}_{\text {uncr }}=\frac{\mathrm{b} \cdot \mathrm{h}_{\mathrm{c}}{ }^{3}}{12 \cdot \mathrm{n}}+\frac{\mathrm{b} \cdot \mathrm{h}_{\mathrm{c}}}{\mathrm{n}} \cdot\left(\mathrm{y}_{\mathrm{u}}-\frac{\mathrm{h}_{\mathrm{c}}}{2}\right)^{2}+\frac{\mathrm{b}_{\mathrm{m}} \cdot \mathrm{h}_{\mathrm{Sd}}{ }^{3}}{12 \cdot \mathrm{n}}+\frac{\mathrm{b}_{\mathrm{m}} \cdot \mathrm{h}_{\mathrm{p}}}{\mathrm{n}} \cdot\left(\mathrm{h}_{\mathrm{total}}-\mathrm{y}_{\mathrm{u}}-\frac{\mathrm{h}_{\mathrm{Sd}}}{2}\right)^{2}+\mathrm{A}_{\mathrm{Sd}} \cdot\left(\mathrm{y}_{\mathrm{Sd}}-\mathrm{x}_{\mathrm{u}}\right)^{2}+\mathrm{I}_{\mathrm{Sd}}=10,337,783 \mathrm{~mm}^{4} / \mathrm{m}$. (on steel modulus)

In which $\mathrm{y}_{\mathrm{uncr}}$ is the position of the neutral axis in the uncracked section (Equation 30). 
$\mathrm{y}_{\text {uncr }}=\frac{\mathrm{b} \cdot \frac{\mathrm{h}_{\mathrm{c}}{ }^{2}}{2}+\mathrm{b}_{\mathrm{m}} \cdot \mathrm{h}_{\mathrm{Sd}} \cdot\left(\mathrm{h}-\frac{\mathrm{h}_{\mathrm{Sd}}}{2}\right)+\mathrm{n} \cdot \mathrm{A}_{\mathrm{Sd}} \cdot \mathrm{y}_{\mathrm{Sd}}}{\mathrm{b} \cdot \mathrm{h}_{\mathrm{c}}+\mathrm{b}_{\mathrm{m}} \cdot \mathrm{h}_{\mathrm{Sd}}+\mathrm{n} \cdot \mathrm{A}_{\mathrm{Sd}}}=57.67 \mathrm{~mm}$.

Second moment of area of the cracked section, $\mathrm{I}_{\mathrm{cr}}$, for $\mathrm{b}=1,000 \mathrm{~mm}$ (Equation 31 ):

$I_{c r}=\frac{b \cdot y_{c}^{3}}{3 \cdot n}+A_{p} \cdot\left(y_{S d}-y_{c}\right)^{2}+I_{S d}=5,355,816 \mathrm{~mm}^{4} / \mathrm{m}$.

The neutral axis position of the cracked section to the top of the slab $y_{\mathrm{cr}}$ is by Equation 32 .

$\mathrm{y}_{\mathrm{cr}}=\frac{\Sigma \mathrm{A}_{\mathrm{i}} \cdot \mathrm{z}_{\mathrm{i}}}{\Sigma \mathrm{A}_{\mathrm{i}}}=\frac{\mathrm{n} \cdot \mathrm{A}_{\mathrm{p}}}{\mathrm{b}}\left(\sqrt{1+\frac{2 \cdot \mathrm{b} \cdot \mathrm{d}_{\mathrm{Sd}}}{\mathrm{n} \cdot \mathrm{A}_{\mathrm{Sd}}}}-1\right)=39.29 \mathrm{~mm}$.

The average value of second moment of area ( $\left.\mathrm{I}_{\mathrm{cm}}\right)$ for cracked ( $\left.\mathrm{I}_{\mathrm{cr}}\right)$ and uncracked ( $\left.\mathrm{I}_{\text {uncr }}\right)$ section is (seen Equation 3):

$\mathrm{I}_{\mathrm{cm}}=\frac{\mathrm{I}_{\mathrm{uncr}}+\mathrm{I}_{\mathrm{cr}}}{2}=\frac{10,337,783+5,355,816}{2}=7,846,800 \mathrm{~mm}^{4} / \mathrm{m}$.

The expression of predicted deflection takes into account the cracking effects with average second moment of area and is based on the reduction in half of the concrete's modulus of elasticity.

\subsection{Prediction of AS/NZS 2327 approach}

According to the experimental test and considered evaluation approach, the composite slabs have the followings deflections components:

- Instantaneous deflections: due self-weight $\left(\delta_{0,8 \mathrm{~d}}\right)$ and imposed load $\left(\delta_{1,28 \mathrm{~d}}\right)$;

- Time-dependent deflections: due creep component: imposed load $\left(\delta_{\mathrm{cc}, 1}\right)$ e shrinkage component: $\left(\delta_{\mathrm{cs}}\right)$.

Based on the equations presented in Section 3.2, each component is calculated. Table 2 presents a summary of them.

Table 2. Data for analysis using section rigidities at $t_{0}$

\begin{tabular}{cccccc}
\hline Input data & Unit & $\begin{array}{c}\text { Concrete (c) } \\
\text { Uncracked section }\end{array}$ & $\begin{array}{c}\text { Concrete (c) } \\
\text { Cracked section }\end{array}$ & $\begin{array}{c}\text { Steel } \\
\text { Decking (sd) }\end{array}$ & $\begin{array}{c}\text { Steel } \\
\text { mesh (s) }\end{array}$ \\
\hline Cross-section area $(A)$ & $\mathrm{mm}^{2} / \mathrm{m}$ & $97,454.4$ & 29.933 & 975 & 102 \\
\hline First area moment $(B)$ & $\mathrm{mm}^{3} / \mathrm{m}$ & $7,163,690.7$ & $3,293,668$ & $26,812.5$ & 9695.6 \\
\hline Second moment of area $(I)$ & $\mathrm{mm}^{4} / \mathrm{m}$ & $635,595,091$ & $364,648,226$ & $1,302,894$ & 921,189 \\
\hline Elastic modulus $(E)$ & $\mathrm{N} / \mathrm{mm}^{2}$ & 30,000 & 30.000 & 204,000 & 191,000 \\
\hline Uncracked section: & & $\mathrm{R}_{\mathrm{A}, 0, \mathrm{uncr}}=3,139 \times 10^{6} \mathrm{~N} ; \mathrm{R}_{\mathrm{B}, 0}=2,219 \times 10^{8} \mathrm{Nmm} ; \mathrm{R}_{\mathrm{I}, 0}=1,948 \times 10^{10} \mathrm{Nmm}^{2}$ \\
\hline Cracked section: & & $\mathrm{R}_{\mathrm{A}, 0, \mathrm{cr}}=1,113 \times 10^{6} \mathrm{~N} ; \mathrm{R}_{\mathrm{B}, 0, \mathrm{cr}}=1,058 \times 10^{8} \mathrm{Nmm} ; \mathrm{R}_{\mathrm{I}, 0, \mathrm{cr}}=1,135 \times 10^{10} \mathrm{Nmm}^{2}$
\end{tabular}

The cracking moment for the composite section without taking into account the shrinkage effects is $\mathrm{M}_{\mathrm{cr}}=8.34 \mathrm{kNm}$. The tensile stress induced by shrinkage is obtained, according to Equations 7, 11, 12. At age 10.000-days, the predicted shrinkage deformation is $\varepsilon_{\mathrm{cs}}(\infty, 7)=-548 \cdot 10^{-6}$ and creep coefficient $\varphi(\infty, 28)=2.48$. Both calculated according to Brazilian code NBR 6118 [23] Annex A recommendations. The stress-induced shrinkage at the bottom face of concrete is $\sigma_{\mathrm{cs}}=0.96 \mathrm{MPa}$ and the cracking moment is reduced for $\mathrm{M}_{\mathrm{cr}, \mathrm{cs}(\infty)}=6.10 \mathrm{kNm}(\approx-27 \%)$. 


\section{Instantaneous deflections components}

The second moment of area (I) based on the initial stiffness, as there was no cracking, is given by Equation 22. If the section is cracked, Equation 6 is used.

$\mathrm{I}_{\mathrm{uncr}}=\frac{1,948 \times 10^{10} \cdot 3,139 \times 10^{6}-\left(2,219 \times 10^{8}\right)^{2}}{3,139 \times 10^{6} \cdot 30,000}=126.3 \times 10^{6} \mathrm{~mm}^{4} / \mathrm{m}($ on concrete modulus $)$.

The in-service flexural moment at 8-days due self-weight $\mathrm{p}_{0,8}=2.40 \mathrm{kPa}$ is $\mathrm{M}_{\mathrm{s}, 8}=2.70 \mathrm{kNm}<\mathrm{M}_{\mathrm{cr}}$. The instantaneous deflection is $\delta_{0,8 \mathrm{~d}}=0.67 \mathrm{~mm}$. In-service flexural moment at 28-days, plus imposed load $\left(\mathrm{p}_{1,28}=2.26 \mathrm{kPa}\right)$ produces $\mathrm{M}_{\mathrm{s}, 8}=5.02 \mathrm{kNm}<\mathrm{M}_{\mathrm{cr}}$. The second part of the instantaneous deflection is $\delta_{0,28 \mathrm{~d}}=0.63 \mathrm{~mm}$. The total instantaneous deflection is $\delta_{0, \text { tot }}=1.30 \mathrm{~mm}$.

\section{Creep deflection component}

The total creep deflection component for imposed load $\left(\delta_{\mathrm{cc}, \mathrm{sobl}, \infty}\right)$ is given by Equations 14 and 15 . The effective creep module for the imposed load, with creep coefficient $\varphi(\infty, 8)=2.48$ is $\mathrm{E}_{\mathrm{ef}, \mathrm{cc}}=8,618 \mathrm{MPa}$. The effective inertias $\mathrm{I}_{\mathrm{ef}}$ and $\mathrm{I}_{\mathrm{ef}, \mathrm{cc}}$ are calculated with modules $\mathrm{E}_{\mathrm{c}}$ and $\mathrm{E}_{\mathrm{ef}, \mathrm{cc}}$, respectively, taking into account the possibility of cracking and, consequently, tension-stiffening effects. Calculating the inertia for effective creep modulus $\left(\mathrm{E}_{\mathrm{ef}, \mathrm{cc}}\right)$, one obtains $\mathrm{I}_{\mathrm{ef}}=164 \times 10^{6} \mathrm{~mm}^{4} / \mathrm{m}$. Therefore, $\alpha_{\mathrm{cc}, \mathrm{sobl}(\infty)}=1.68$ and $\delta_{\mathrm{cc}, \infty}=0.63 \mathrm{~mm} \cdot 1.68=1.06 \mathrm{~mm}$. The creep deflection component is $\delta_{\mathrm{cc}}=1.06 \mathrm{~mm}$.

\section{Shrinkage deflection component}

The total shrinkage deflection component $\left(\delta_{\mathrm{cs}, \infty}\right)$ is determined based on the curvature induced by $\kappa_{\mathrm{cs}}$ shrinkage. The effective concrete modulus for shrinkage $E_{\text {ef,cs }}$ is calculated according to Equation 19 and the reference shrinkage deformation $\varepsilon_{\mathrm{r}, \mathrm{cs}, \infty}$ and curvature $\kappa_{\mathrm{r}, \mathrm{css}, \infty}$, as shown in Figure 2. Given the non-occurrence of cracking in the crosssection, uncracked inertia of the concrete was used. Table 3 presents the data summary for obtaining the curvatures due to non-uniform shrinkage.

Table 3. Data summary for non-uniform shrinkage parameters

\begin{tabular}{cll}
\hline $\mathrm{E}_{\text {ef }, \mathrm{cs}}=12,687 \mathrm{MPa} ;$ & $\mathrm{A}_{\mathrm{c}, \text { uncr }}=97,454.4 \mathrm{~mm}^{2} ;$ & $\mathrm{R}_{\mathrm{A}, \mathrm{cs}, \text { uncr }}=1453.5 \times 10^{6} \mathrm{~N} ;$ \\
\hline$\varepsilon_{\mathrm{r}, \mathrm{cs}, \infty}=-110 \cdot 10^{-6} \mathrm{~mm} / \mathrm{mm} ;$ & $\mathrm{B}_{\mathrm{c}, \text { uncr }}=-7,163,691 \mathrm{~mm}^{3} ;$ & $\mathrm{R}_{\mathrm{B}, \mathrm{cs}, \text { uncr }}=-980.9 \times 10^{8} \mathrm{Nmm} ;$ \\
\hline$\kappa_{\mathrm{r}, \mathrm{cs}, \infty}=-4.38 \mathrm{~mm}^{-1} ;$ & $\mathrm{I}_{\mathrm{c}, \text { uncr }, \mathrm{r}}=635.6 \times 10^{6} \mathrm{~mm}^{4} ;$ & $\mathrm{R}_{0, \mathrm{cs}, \text { uncr }}=2725.4 \cdot 10^{18} \mathrm{~N}^{2} \mathrm{~mm}^{2}$. \\
\hline
\end{tabular}

The curvature of the composite slabs section is obtained according to Equation 20.

$\kappa_{\mathrm{cs}, \text { uncr }, \infty}=\left[\begin{array}{ll}\frac{\mathrm{R}_{\mathrm{B}, \mathrm{cs}, \text { uncr }}}{\mathrm{R}_{0, \mathrm{cs} \text {,uncr }}} & \frac{\mathrm{R}_{\mathrm{A}, \mathrm{cs} \text {,uncr }}}{\mathrm{R}_{0, \mathrm{cs}, \text { uncr }}}\end{array}\right] \mathrm{E}_{\mathrm{ef}, \mathrm{cs}}\left[\begin{array}{c}\mathrm{A}_{\mathrm{c}, \text { uncr }} \cdot \varepsilon_{\mathrm{r}, \mathrm{cs}}-\mathrm{B}_{\mathrm{c}, \mathrm{uncr}} \cdot \kappa_{\mathrm{r}, \mathrm{cs}} \\ -\mathrm{B}_{\mathrm{c}, \text { uncr }} \cdot \varepsilon_{\mathrm{r}, \mathrm{cs}}+\mathrm{I}_{\mathrm{c}, \text { uncr }} \cdot \kappa_{\mathrm{r}, \mathrm{cs}}\end{array}\right]=-4.95 \cdot 10^{-6} \mathrm{~mm}^{-1}$.

The maximum long-term shrinkage deflection is given by Equation 20 .

$\delta_{\mathrm{cs}(\infty)}=\frac{\kappa_{\mathrm{cs}} \cdot \mathrm{L}^{2}}{8}=\frac{4.95 \cdot 10^{-6} \cdot 3,000^{2}}{8}=5.57 \mathrm{~mm}$. 
Therefore, the deflection by AS/NZS 2327 [5] calculation has a final predicted value of instantaneous component equal $\delta_{0, \text { tot }}=1.30 \mathrm{~mm}$ and the long-term component of $\left(\delta_{\mathrm{cc}}+\delta_{\mathrm{cs}}\right)=6.63 \mathrm{~mm}$. The total deflection predicted is the sum of all components $\delta_{\text {tot }}\left(\delta_{0}+\delta_{\mathrm{cc}}+\delta_{\mathrm{cs}}\right)=7.93 \mathrm{~mm}$. The non-uniform shrinkage being the most representative component, which for the slab calculation represented $70 \%$ of the total deflection predicted.

\section{DISCUSSIONS OF THE AUTHOR'S EXPERIMENTAL RESULTS}

The Brazilian code NBR 8800 [11] includes in its Annex Q normative guidelines for composite steel-concrete slabs. For serviceability criteria, it states that the maximum deflection must be less than the ratio of the theoretical $\operatorname{span} \mathrm{L}_{\mathrm{F}} / 350$, considering only the effect of the live loads. However, it does not provide any indication for deflection evaluations. The international codes Eurocode 4 [4] and AS/NZS 2327 [5] provide further guidance, highlighting the usual limitation of $\mathrm{L}_{\mathrm{F}} / 250$ for actions by the quasi-permanent combination.

The results presented by the two evaluation approaches for the same in-service loading were $3.07 \mathrm{~mm}$ and $7.93 \mathrm{~mm}$, respectively, for the EC4 [4] and AS/NZS 2327 [5] approaches for total deflection. A significant difference between them, with the Australian approach considering the time-dependent effects, and presenting higher values of deflection than the Eurocode 4 approach.

The deflection predicted for the imposed load has a value corresponding to $48.5 \%$ (1.49 $\mathrm{mm}$ ) of the total deflection $(3.07 \mathrm{~mm})$ for the Eurocode 4 [4] approach. In the AS/NZS 2327 [5] approach, instantaneous deflection is $0.63 \mathrm{~mm}$ and the creep deflection $1.06 \mathrm{~mm}$ (total $1.69 \mathrm{~mm}$ ). Shrinkage deflection occurs without the influence of loadings.

The AS/NZS 2327 [5] approach shows good accuracy compared to the experimental results. The shrinkage strain and creep coefficient were calculated based on the model of Annex A of the Brazilian Standard ABNT NBR 6118:2014 [23]. Figure 10 shows the results for experimental data and theoretical predictions by AS/NZS 2327 [5] over time and the deflection value with EC4 [4] approach.

The evolution of the long-term deflection can be observed, reaching an asymptote in a long-time of the effects of shrinkage and creep concrete. An age 10.000-days was taken for the comparative analysis. For the test age of 134 days with the imposed load, the instantaneous deflection is observed in the jumps (Figure 10). The final experimental deflection was $4,40 \mathrm{~mm}$, compared to the analytical-theoretical prediction of $4.54 \mathrm{~mm}$, (Experimental / Predicted) equals 0.97 .

Table 4 shows the results of the experimental and theoretical analysis using the simplified approach of the code AS/NZS 2327 [5].

Table 4. Results of experimental and theoretical deflection by AS/NZS 2327 approach

\begin{tabular}{|c|c|c|c|c|c|c|c|c|}
\hline \multirow{2}{*}{ Measured } & \multicolumn{3}{|c|}{$\begin{array}{c}\text { Instantaneous deflection } \\
\text { (Inst.) }\end{array}$} & \multicolumn{3}{|c|}{$\begin{array}{c}\text { Long-term deflection } \\
\text { (L.T.) }\end{array}$} & \multirow{2}{*}{$\begin{array}{c}\text { Total } \\
\text { deflection } \\
\text { (Inst.+L.T.) }\end{array}$} & \multirow{2}{*}{$\begin{array}{c}\text { Ratio } \\
(\text { Inst.)/(LT) }\end{array}$} \\
\hline & $\begin{array}{c}\text { Self- } \\
\text { weight (1) }\end{array}$ & $\begin{array}{l}\text { Imposed } \\
\text { Load (2) }\end{array}$ & Total & $\begin{array}{l}\text { 8-28 } \\
\text { days }\end{array}$ & $\begin{array}{l}29-134 \\
\text { days }\end{array}$ & Total & & \\
\hline Experimental & 0.35 & 0.65 & 1.00 & 1.65 & 1.82 & 3.47 & 4.47 & 3.47 \\
\hline Predicted & 0.67 & 0.63 & 1.30 & 0.97 & 2.30 & 3.27 & 4.57 & 2.52 \\
\hline $\begin{array}{c}\text { Ratio } \\
\text { Exp./Pred) }\end{array}$ & 0.52 & 1.03 & 0.77 & 1.76 & 0.79 & 1.06 & 0.98 & - \\
\hline
\end{tabular}

Compared to the instantaneous deflection, there is $($ Exp. $=1.00 \mathrm{~mm} /$ Pred. $=1.30 \mathrm{~mm})$, a ratio of 0.77 . For the instantaneous deflection component due imposed load, we have (Exp. $=0.65 \mathrm{~mm} /$ Pred. $=0.63 \mathrm{~mm}$ ), a ratio of 1.03 . The long-term deflection showed an experimental value of $3.47 \mathrm{~mm}$, against an analytically predicted value of 3.27 $\mathrm{mm}($ Exp./Pred. $=1.06)$. The long-term deflection predicted is 2.52 times larger than the instantaneous deflection at this age (134-days). In this way, the approach is more accurate in predicting deflections. 


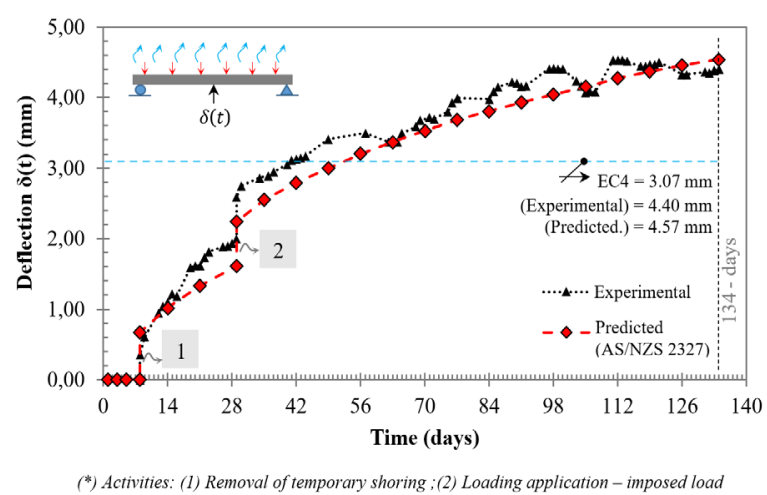

Figure 10. Results of experimental test for composite slabs and predicted deflections by simplified method AS/NZS 2327 [5]

Compared to the instantaneous deflection, there is $($ Exp. $=1.00 \mathrm{~mm} /$ Pred. $=1.30 \mathrm{~mm})$, a ratio of 0.77 . For the instantaneous deflection component due imposed load, we have $($ Exp. $=0.65 \mathrm{~mm} /$ Pred. $=0.63 \mathrm{~mm})$, a ratio of 1.03 . The long-term deflection showed an experimental value of $3.47 \mathrm{~mm}$, against an analytically predicted value of $3.27 \mathrm{~mm}$ (Exp./Pred. $=1.06)$. The longterm deflection predicted is 2.52 times larger than the instantaneous deflection at this age (134-days). In this way, the approach is more accurate in predicting deflections.

For the extrapolation of data, as shown for the presented example, the final deflection at age 10,000-days is $6.63 \mathrm{~mm}$. For the age of 134-days, the occurred deflection represents around $50 \%$ of the long-term effects. Thereby even a test with relatively short duration allows reassuring the need of taking into account the long-term effects for more accurate analysis.

\section{RESULTS AND DISCUSSIONS OF THE LITERATURE EXPERIMENTAL}

In order to obtain a complete picture of design code deflection calculation for steel-concrete composite slabs, experimental results from the literature were also considered in this study. These studies include experimental tests of 12 simply-supported slabs.

Al-Deen et al. [10] tested 2 composite slabs, with a span of 3,000 $\mathrm{mm}$ and slab thickness of $180 \mathrm{~mm}$, without imposed load. They used a clip-pan profile steel decking and normal concrete. The duration was 239 days. Gholamhoseini [8][9] tested 10 slabs, with a span of 3,100 $\mathrm{mm}$ and slab thickness of $150 \mathrm{~mm}, 2$ without and 8 with an imposed load. Each five slabs used one trapezoidal type steel decking and normal concrete. The duration test evaluated varied in 197-251 days.

Table 5 shows the summary of specimens evaluated. The Slabs ID brings the original names by the authors. The self-weight and imposed load are presented in $\mathrm{kPa}$.

Table 5. Simply-supported composite slabs: long-term experimental results in literature

\begin{tabular}{|c|c|c|c|c|c|c|c|}
\hline Author(s) & $\begin{array}{l}\text { Slab } \\
\text { ID }\end{array}$ & $\begin{array}{c}\text { Profiled } \\
\text { Steel Decking }\end{array}$ & $\begin{array}{l}\text { Span } \\
(\mathbf{m m})\end{array}$ & $\begin{array}{c}\text { Slab } \\
\text { Thickness } \\
(\mathbf{m m})\end{array}$ & $\begin{array}{l}\text { Self-weight } \\
\text { (kPa) }\end{array}$ & $\begin{array}{c}\text { Imposed } \\
\text { Load } \\
(\mathrm{kPa}) \\
\end{array}$ & $\begin{array}{c}\text { Duration } \\
\text { test } \\
\text { (days) }\end{array}$ \\
\hline \multirow{2}{*}{ Al-deen et al. [10] } & $\mathrm{CS} 1$ & \multirow{2}{*}{$\begin{array}{c}\text { Condeck HP55 }^{\mathrm{a}} \\
{[24]}\end{array}$} & \multirow{2}{*}{3000} & \multirow{2}{*}{180} & \multirow{2}{*}{4.40} & None & \multirow{2}{*}{239} \\
\hline & $\mathrm{CS} 2$ & & & & & None & \\
\hline \multirow{10}{*}{ Gholamhoseini [8] [9] } & 1LT-70-0 & \multirow{5}{*}{$\begin{array}{l}\text { Filders KF70 } \\
\text { [25] }\end{array}$} & \multirow{5}{*}{3100} & \multirow{5}{*}{150} & \multirow{5}{*}{3.00} & None & \multirow{4}{*}{247} \\
\hline & 2LT-70-3 & & & & & 3.40 & \\
\hline & 3LT-70-3 & & & & & 3.40 & \\
\hline & $4 \mathrm{LT}-70-6$ & & & & & 6.00 & \\
\hline & 5LT-70-6 & & & & & 6.00 & 197 \\
\hline & 6LT-40-0 & \multirow{5}{*}{$\begin{array}{l}\text { Filders KF40 } \\
\text { [25] }\end{array}$} & \multirow{5}{*}{3100} & \multirow{5}{*}{150} & \multirow{5}{*}{3.20} & None & 244 \\
\hline & $7 \mathrm{LT}-40-3$ & & & & & 3.40 & \multirow{4}{*}{251} \\
\hline & $8 \mathrm{LT}-40-3$ & & & & & 3.40 & \\
\hline & 9LT-40-6 & & & & & 6.40 & \\
\hline & $10 \mathrm{LT}-40-6$ & & & & & 6.40 & \\
\hline
\end{tabular}

\footnotetext{
${ }^{\text {a }}$ Profile steel decking clip-pan type: $0.75 \mathrm{~mm}$ Stramit Condeck HP55 [24]
}

b, c Profile steel decking trapezoidal type: $0.75 \mathrm{~mm} \mathrm{KF} 40$ and KF70 [25] 
The characteristics of the composite slabs, as geometrical and materials properties are summarised in Table 6 . These works brought the characteristics of the steel decking, loads and environmental conditions and, characteristics of the concrete, elastic modulus and flexural tensile strength.

These twelve composite slabs were used to compare experimental results to the provisions by AS/NZS 2327 [5]. The slabs of Al-deen et al. [10] and Gholamhoseini [8] [9] were referred to the Australian Standard AS 3600:2018 [26] for concrete creep and shrinkage models, since they were designed considering local materials and conditions.

The composite slabs were uncracked for the given load. In the occurrence of cracking, the effects of creep and shrinkage on the deflection shall increase, considering the reduction in the stiffness of the cracked cross-sections.

Table 6. Characteristics of the composite slabs in literature

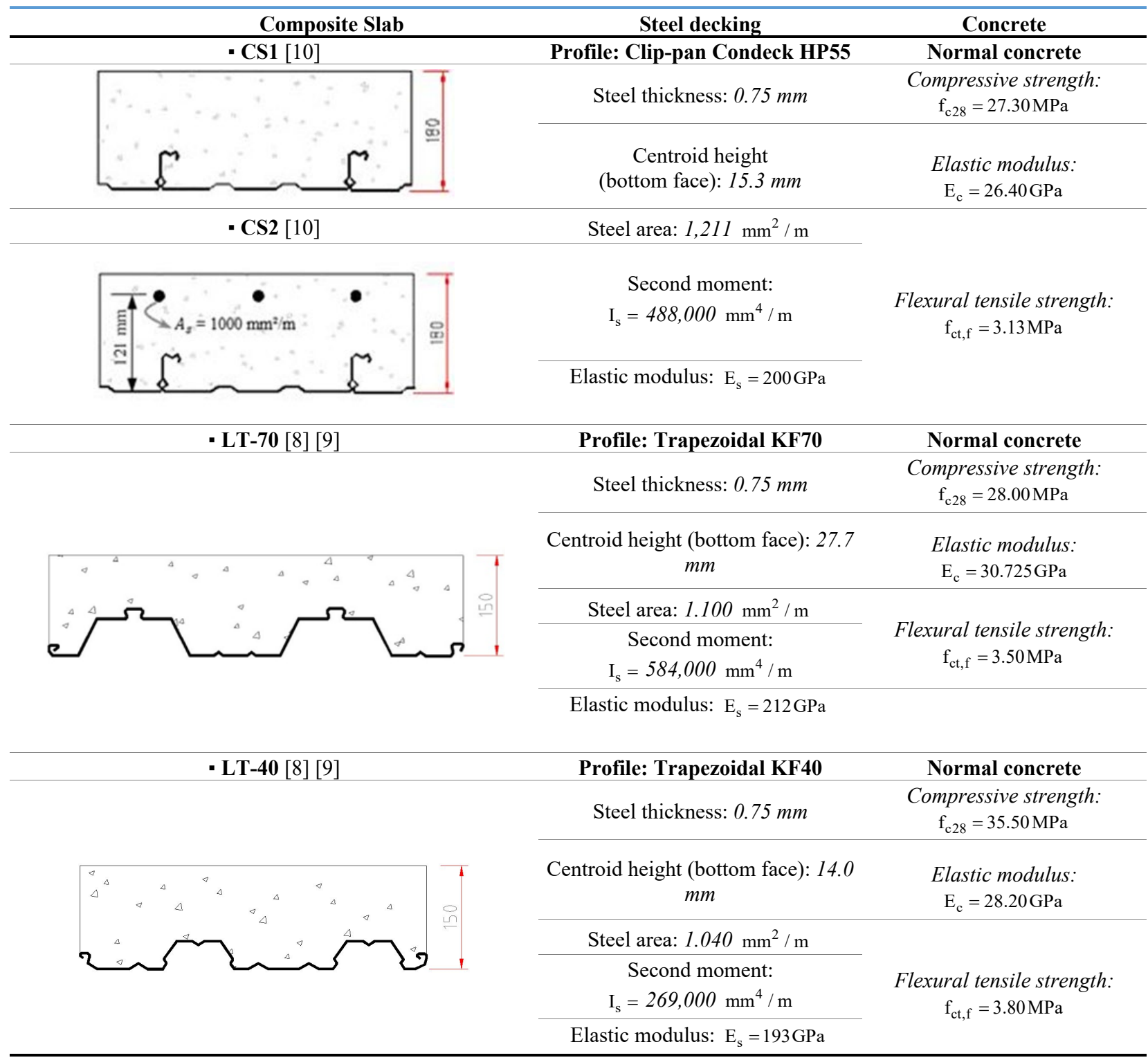

Figure 11 show experimental results compared with deflection calculation by code AS/NZS 2327 [5] approach in the simply-supported composite slabs in long-term tests. In comparison, the values of the deflection calculated using the EC4 [4] model are shown. The first 4 slabs are subject only to their self-weight. The others 8 slabs have testing pairs and have imposed loads in the order of the self-weight and double it. 
A good accuracy between experimental and predicted long-term deflections was observed (Figure 11) with obtained ratio (Exp./Pred.) ranging between $(0.88-1.14)$ as presented in Table 7 , with average equal 0.99 and coefficient of variation (c.o.v) of $9.6 \%$. The long-time deflection calculation adopted the procedure shown in Section 3.2. This simplified method proposed by AS/NZS 2327 [5] used materials and geometric properties from tests presented in the literature and performed by authors to compare the predicted deflections to the measured ones.

Table 7 provides a comparative evaluation of the results at the end of the performed tests considering measured values and deflections predicted by the AS/NZS 2327 [5] approach. A second comparison considers the final deflections for long-time at $t_{\infty}$ given by AS/NZS 2327 [5], BS5950 [21] and Eurocode 4 [4] models, using reduced elasticity modulus of concrete with $2 / 3 \mathrm{E}_{\mathrm{cm}}, 1 / 3 \mathrm{E}_{\mathrm{cm}}$ and $1 / 2 \mathrm{E}_{\mathrm{cm}}$, respectively, for each tested slab. Figure 12 summarizes the comparative results of the deflections evaluations.

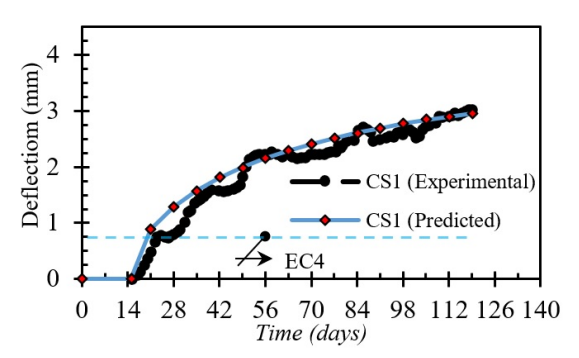

(a) CS 1

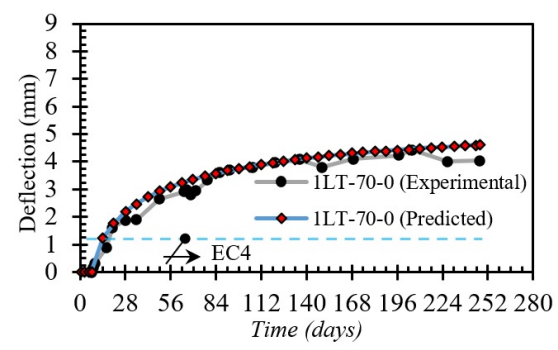

(c) 1LT-70-0

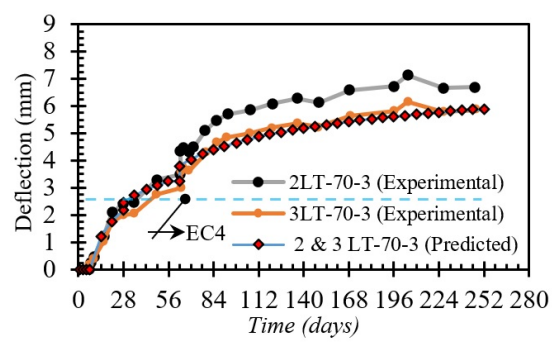

(e) 2LT-70-3 and 3LT-70-3

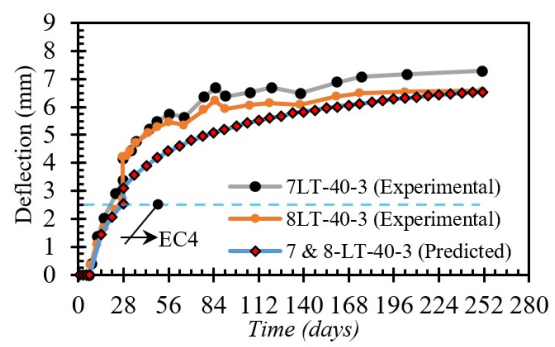

(g) 7 LT-40-3 and 8LT-40-3

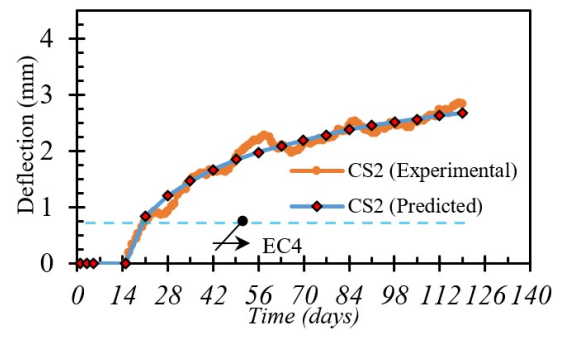

(b) CS2

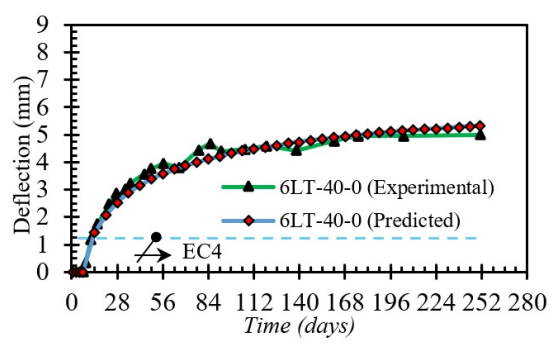

(d) 6LT-40-0

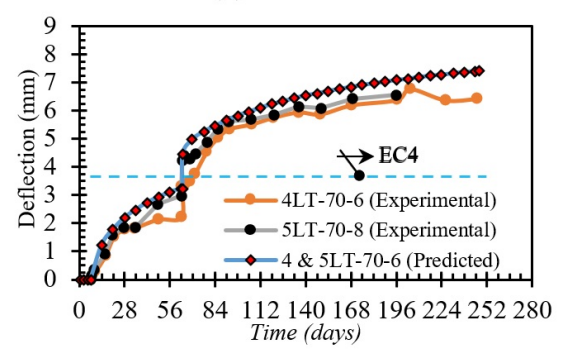

(f) 4LT-70-6 and 5LT-70-6

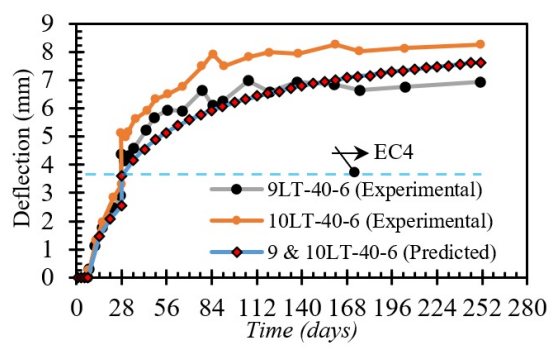

(h) 9 LT-40-6 and 10LT-40-6

Figure 11. Comparisons between experimental and theoretical predicted (AS/NZS 2327) deflections of simply-supported composite slabs in long-term tests 
Table 7. Deflection calculation using design codes compared to experimental tests results

\begin{tabular}{|c|c|c|c|c|c|c|c|c|c|}
\hline \multirow[b]{2}{*}{ Slabs ID } & \multirow{2}{*}{$\begin{array}{c}\text { Imposed } \\
\text { Load } \\
\text { / Self- } \\
\text { weight }\end{array}$} & \multicolumn{3}{|c|}{$\begin{array}{l}\text { Deflections at the } \\
\text { end of test (t) }\end{array}$} & \multicolumn{5}{|c|}{$\begin{array}{c}\text { Final predicted } \\
\text { deflection }\end{array}$} \\
\hline & & $\begin{array}{c}\text { Tests } \\
\text { Results } \\
(\mathrm{mm})^{(1)}\end{array}$ & $\begin{array}{c}A S / N Z S \\
2327 \\
(\mathrm{~mm})^{(2)}\end{array}$ & $\underset{\text { Ratio* }}{\text { (1) } /(2)}$ & $\begin{array}{c}A S / N Z S \\
2327\left(\mathrm{t}_{\infty}\right) \\
(\mathrm{mm})^{(3)}\end{array}$ & $\begin{array}{c}\text { BS5950 } \\
\left(2 / 3 \mathrm{E}_{\mathrm{cm}}\right) \\
(\mathbf{m m})^{(4)}\end{array}$ & $\begin{array}{l}\left(\mathrm{E}_{\mathrm{cm}} / 3\right) \\
(\boldsymbol{m} \boldsymbol{m})^{(5)}\end{array}$ & $\begin{array}{c}\boldsymbol{E C 4} \\
\left(\mathrm{E}_{\mathrm{cm}} / 2\right) \\
(\mathbf{m m})^{(6)}\end{array}$ & $\underset{(3) /(6)}{\text { Ratio }^{* *}}$ \\
\hline CS1 & \multirow{4}{*}{ None } & 3.02 & 2.96 & $(1.02)$ & 5.17 & 0.67 & 1.05 & 0.81 & $(6.38)$ \\
\hline $\mathrm{CS} 2$ & & 2.85 & 2.68 & $(1.06)$ & 4.48 & 0.65 & 0.99 & 0.78 & $(5.74)$ \\
\hline $1 \mathrm{LT}-70-0$ & & 4.04 & 4.60 & $(0.88)$ & 6.11 & 1.01 & 1.56 & 1.22 & $(5.01)$ \\
\hline $6 \mathrm{LT}-40-0$ & & 4.99 & 5.33 & $(0.94)$ & 7.24 & 1.04 & 1.58 & 1.24 & (5.84) \\
\hline 2LT-70-3 & \multirow{2}{*}{1.13} & 6.70 & \multirow{2}{*}{5.87} & (1.14) & \multirow{2}{*}{7.40} & \multirow{2}{*}{2.15} & \multirow{2}{*}{3.33} & \multirow{2}{*}{2.60} & \multirow{2}{*}{$(2.85)$} \\
\hline 3LT-70-3 & & 5.86 & & $(1.00)$ & & & & & \\
\hline 7LT-40-3 & \multirow{2}{*}{1.06} & 7.30 & \multirow{2}{*}{6.55} & $(1.11)$ & \multirow{2}{*}{8.75} & \multirow{2}{*}{2.14} & \multirow{2}{*}{3.27} & \multirow{2}{*}{2.56} & \multirow{2}{*}{$(3.42)$} \\
\hline $8 \mathrm{LT}-40-3$ & & 6.57 & & $(1.00)$ & & & & & \\
\hline 4LT-70-6 & \multirow{4}{*}{2.00} & 6.76 & 7.41 & $(0.91)$ & \multirow{2}{*}{10.86} & \multirow{2}{*}{3.03} & \multirow{2}{*}{4.69} & \multirow{2}{*}{3.65} & \multirow{2}{*}{ (2.98) } \\
\hline $5 \mathrm{LT}-70-6$ & & 6.58 & 7.08 & $(0.93)$ & & & & & \\
\hline 9LT-40-6 & & 6.94 & \multirow{2}{*}{7.63} & $(0.91)$ & \multirow{2}{*}{10.06} & \multirow{2}{*}{3.11} & \multirow{2}{*}{4.75} & \multirow{2}{*}{3.73} & \multirow{2}{*}{$(2.70)$} \\
\hline 10LT-40-6 & & 8.26 & & (1.08) & & & & & \\
\hline \multirow[t]{3}{*}{ Presented } & 0.94 & 4.40 & 4.57 & $(0.98)$ & 7.93 & 2.54 & 3.86 & 3.07 & $(2.58)$ \\
\hline & & & \multicolumn{2}{|c|}{ Average $=0.99 *$} & \multicolumn{5}{|c|}{ Average $=5.74 /$ C.O.V $=9.8 \%($ No imposed load $) * *$} \\
\hline & & & \multicolumn{2}{|c|}{ C.O.V $=9.6 \% *$} & \multicolumn{5}{|c|}{ Average $=2.90 /$ C.O.V $=11.1 \%($ With imposed load $) * *$} \\
\hline
\end{tabular}

* Ratio between experimental results ${ }^{(1)}$ and predicted deflection by AS/NZS $2327^{(2)}$ at end age of test (t).

** Ratio between total deflection AS/NZS 2327 at infinite time $\left(\mathrm{t}_{\infty}\right)^{(3)}$ and EC4 approach ${ }^{(6)}$

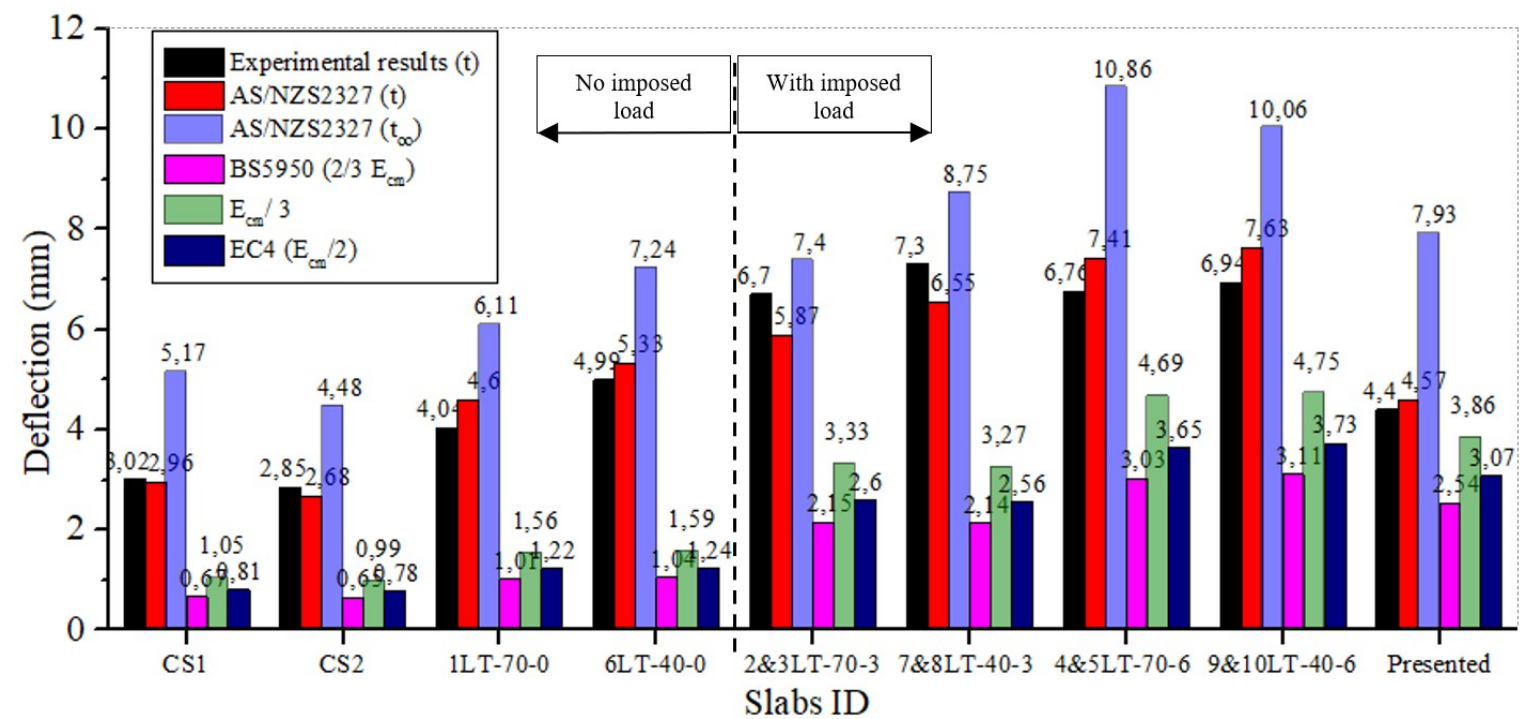

Figure 12. Comparisons between experimental results (black color) and theoretical predictions deflections of simply-supported composite slabs in long-term tests

The final predicted deflections by the analysed codes for the first four studied slabs, with no imposed load, presented a massive difference between obtained values, being 5.01-6.38 (average $=5.74$ and C.O.V $=9.8 \%$ ) lower for the Eurocode model [4] regarding the AS/NZS approach [5]. For the other eight slabs, plus the one presented by the authors, with imposed load representing 0.94-2.00 of the self-weight, the results showed that for the in-service loading, the predictions of the Eurocode 4 model were 2.58-3.42 (average $=2.90$ and C.O.V $=11.1 \%$ ) lower than the AS/NZS 2327 [5] model. Figure 12 clarifies that strategy of reduced elastic modulus of concrete is not adequate, even using values such as its third part. The deflection component due to the shrinkage was the most expressive contribution for that difference. 
The mean values practiced in the market were represented by the evaluated composite slabs of $3 \mathrm{~m}$ span and 125 to $180 \mathrm{~mm}$ in height of slab, and composed with profile steel decking with $40-75 \mathrm{~mm}$ and steel thicknesses of $0.75 \mathrm{~mm}-$ $1.00 \mathrm{~mm}$. The analyses indicate that for simply supported slabs, the in-service assessment that considered the shrinkage and creep effects enabled results consistent with experimental results in tested time. Based on this first comparation and when performing the extrapolation for a long useful life of the structure to the AS/NZS 2327 model, the values of the EC4 model using different reduced modulus of elasticity of concrete underestimate the evaluations for the total deflections.

Due to the significance of the shrinkage deflection, it may prevail against the $\mathrm{L}_{\mathrm{F}} / 350$ for the live loads. Shrinkage deflection happens regardless of the live loads. However, it is related to the cracking, which can be increased by the greater magnitude of the loads.

For the Brazilian market, an outstanding point is the in-service checks for slabs with lattice joists using the ArcelorMittal Trelifácil system [27] (Figure 13) or steel-bars truss (Wang et al. [28]). The use of this steel form leads to a non-uniform shrinkage, similarly to composite slabs, indicating the application of the methodology for total deflections calculations.

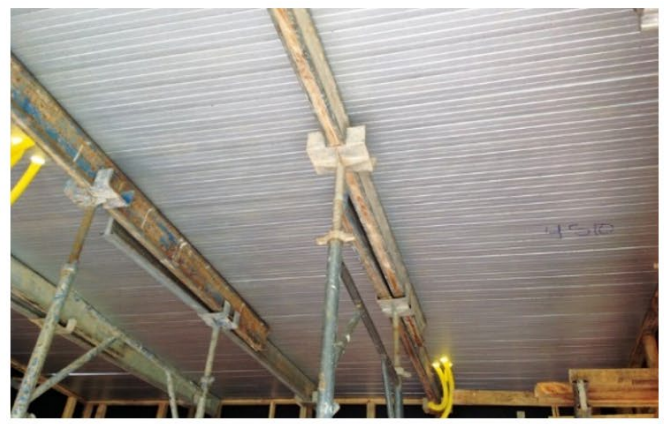

a) Bottom slab with juxtaposed panels [26]

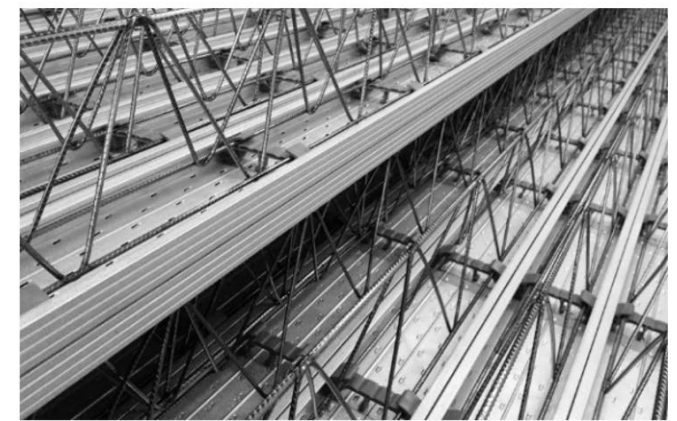

b) Trelifácil lattice slab [26]

Figure 13. Trelifácil system with steel formwork on slab soffit face [27]

AS/NZS 2327 [5] also indicates that the application of surface treatments or the installation of floor coverings can influence and reduce the ability of concrete to dry from its upper face. In these cases, it is possible to reduce the drying shrinkage component used in the deflection calculations reflecting the reduction in drying that occurs from the slab surface, as long as the solution adopted becomes part of the structural design specifications.

\section{CONCLUSIONS}

This paper discussed the deflection evaluation of the serviceability limit state (SLS) for steel-concrete composite slabs, which are presented as a solution for floors in buildings and bridges. Some relevant aspects are highlighted:

- The presentation and comparison of the two main approaches for assessing the deflections demonstrated the difference in complexity and consideration of the variables in the calculations.

- The approach recommended by AS/NZS 2327 [5] showed a total deflection $\delta_{\text {tot }}=7.93 \mathrm{~mm}$ against $\delta_{\text {tot }}=3.07 \mathrm{~mm}$ of Eurocode 4 [4] approach, for the tested slab. So, the first was 2.58 times larger.

- Shrinkage deflection component does not depend directly on the applied load, representing for the numerical example, $70 \%$ of the total deflection. Therefore, it appears that this analysis is essential.

- Given the experimental analysis of the simply-supported composite slab, it was possible to investigate the time-dependent effects over 134-days. It was found that Eurocode 4 underestimated the total deflection, while the AS/NZS 2327 model shows to be accurate compared to the experimental results.

- At the age of 134-days, it is estimated that $50 \%$ of the time-dependents effects have occurred, showing the importance of considering the long-term effects already in the initial ages of buildings. This fact corroborates the application in steel and composite structures, which have a reduced construction time and more immediate use.

- The good accuracy of the simplified approach by AS/NZZS 2327 [5] was evaluated for Brazilian composite slabs, as well as Al-deen et al. [10] and Gholamhoseini [8] [9] Australian slabs; 
- For the experimental results with simply-supported composite slabs under in-service conditions, the calculated final deflections showed that Eurocode 4 [4] can underestimate the values around 2.58-3.42 times, compared to AS/NZS 2327 [5]. Most expressive deflection component was due to shrinkage.

- As a suggestion for future investigations, it recommended the evaluation: of long-term deflection of continuous composite slabs; higher in-service loadings and; the influence of the slabs surface finishing on the effect of drying shrinkage and, consequently, on the time-dependent behaviour of composite slabs.

Therefore, the advance in materials and studies to improve the interaction between steel decking and concrete, obtaining larger spans and/or loads indicate the need of using more representative models. Considering cracking and long-terms effects, such as non-uniform shrinkage and creep in the correct assessment of the in-service behaviour of the composite slabs is progressively more necessary.

\section{ACKNOWLEDGEMENTS}

The authors gratefully acknowledge the financial support provided by the Coordenação de Aperfeiçoamento de Pessoal de Nível Superior - Brasil (CAPES) - Finance Code 001 and São Paulo Research Foundation (FAPESP 2019/03513-5). The authors also appreciate the Modular Building Systems for donating the profiled steel deckings and the technical team of LE-USP laboratory for their supporting in the experimental test.

\section{REFERENCES}

[1] D. A. Souza, "Steel-concrete composite structures", in 56 Brazilian Concr Congr, Natal, 2014 (in Portuguese).

[2] Techne Fast Construction, "Steel-concrete composite slabs system" (in Portuguese). (accessed Nov 1, 2020). Available: http://techne.pini.com.br/engenharia-civil/179/construcao-rapida-sistema-misto-que-dispensa-parcial-ou-totalmente-287917-1.aspx

[3] R. Abdullah, "Experimental evaluation and analytical modelling of shear bond in composite slabs", PhD dissertation, Virginia Polytech. Inst. and State University, Blacksburg, 2004.

[4] The European Union, Eurocode 4 - Design of Composite Steel and Concrete Structures - Part 1-1: General Rules for Buildings, EN 1994-1-1:2004.

[5] Australian Standard/New Zealand Standard, Composite Structures - Composite Steel-Concrete Construction Buildings, AS/NZS 2327:2017.

[6] G. Ranzi, G. Leoni, and R. Zandonini, "State of the art on the time-dependent behaviour of composite steel-concrete structures," $J$. Construct. Steel Res., vol. 80, pp. 252-263, 2013a, http://dx.doi.org/10.1016/j.jcsr.2012.08.005.

[7] G. Ranzi, S. Al-Deen, L. Ambrogi, and B. Uy, "Long-term behaviour of simply-supported post-tensioned composite slabs," $J$. Construct. Steel Res., vol. 88, pp. 172-180, 2013b., http://dx.doi.org/10.1016/j.jcsr.2013.05.010.

[8] A. Gholamhoseini, "Long-term deformation of composite concrete slabs," Concr. Aust., vol. 38, no. 4, pp. 25-32, 2014a., http://dx.doi.org/10.1080/13287982.2016.1238531.

[9] A. Gholamhoseini, "Time-dependent deflection of composite concrete slabs," ACI Struct. J., vol. 111, no. 4, pp. 765-776, 2014b., http://dx.doi.org/10.14359/51686629.

[10] S. Al-Deen, G. Ranzi, and B. Uy, "Non-uniform shrinkage in simply-supported composite steel concrete slabs," Steel Compos. Struct., vol. 18, no. 2, pp. 375-394, 2015., http://dx.doi.org/10.12989/scs.2015.18.2.375.

[11] Associação Brasileira de Normas Técnicas, Projeto de Estruturas de Aço e de Estruturas Mistas de Aço e Concreto de Edificios, ABNT NBR 8800:2008, 2008.

[12] M. Bradford, R. I. Gilbert, R. Zeuner, and G. Brock, "Shrinkage deformations of composite slabs with open trapezoidal sheeting," Procedia Eng., vol. 14, pp. 52-61, 2011, http://dx.doi.org/10.1016/j.proeng.2011.07.006.

[13] R. I. Gilbert, M. A. Bradford, A. Gholamhoseini, and Z. T. Chang, "Effects of shrinkage on the long-term stress and deformations of composite concrete slabs", Eng Struct., vol. 40, pp. 9-19, 2012, https://doi.org/10.1016/j.engstruct.2012.02.016.

[14] R. I. Gilbert, "Time-dependent stiffness of cracked reinforce and composite concrete slabs," Procedia Eng., vol. 57, pp. 19-34, 2013, http://dx.doi.org/10.1016/j.proeng.2013.04.006.

[15] S. Al-Deen and G. Ranzi, "Effects of non-uniform shrinkage on the long-term behavior of composite steel-concrete slabs," Int. J. Steel Struct., vol. 15, no. 2, pp. 415-162, 2015, http://dx.doi.org/10.1007/s13296-015-6012-7.

[16] G. Ranzi, "Service design approach for composite steel-concrete floors," P I Civil Eng-Str B., vol. 171, no. 1, pp. 38-49, 2017, https://doi.org/10.1680/jstbu.16.00196.

[17] M. A. Bradford, "Generic modelling of composite steel-concrete slabs subjected to shrinkage, creep and thermal strains including partial interaction”, Eng Struct., vol. 32, no. 5, pp. 1459-1465, 2010, https://doi.org/10.1016/j.engstruct.2010.01.024.

[18] R. I. Gilbert and G. Ranzi, Time-Dependent Behaviour of Concrete Structures, Nova York: Spon Press, 2011. 
[19] R. P. Johnson, Composite Structures of Steel and Concrete: Beams, Slabs, Columns, and Frames for Buildings, vol. 1, 3rd ed. London: Blackwell Scientific Publications, 2013.

[20] D. Dujmovic, B. Androic, and I. Lukacevic, Composite Structures According to Eurocode 4: Worked Examples. Croatia: Ernst \& Sohn, 2015.

[21] British Standard. Structural Use of Steelwork in Buildings - Part 4: Code of Practice for Design of Composite Slabs with Profiled Steel Sheeting, BS5950-4, 1994.

[22] Modular Sistemas Construtivos, Modular Deck MD 55, Dourados, MS: Modular Sistemas Construtivos, 2018 (in Portuguese).

[23] Associação Brasileira de Normas Técnicas, Projeto de Estruturas de Concreto - Procedimento, ABNT NBR 6118:2014, 2014.

[24] Stramit Condeck HP, Composite Slab System, Product Technical Manual, Queensland, Australia: Stramit Condeck HP, 2012.

[25] Fielders Australia Kingflor, Composite Steel Formwork System Design Manual, Marleston, Australia: Fielders Australia Kingflor, 2008.

[26] Australian Standard/New Zealand Standard, Concrete Structures, AS/NZS 3600:2018, 2018.

[27] ArcelorMittal. "Trelifácil®: much easier to build slabs", São Paulo, SP: ArcelorMittal, 2017 (in Portuguese). 2017 (accessed Nov 1, 2020). Available: http://blog.arcelormittal.com.br/trelifacil-muito-mais-facilidade-para-construir-lajes/

[28] Q. Wang, G. Ranzi, Y. Wang, and Y. Geng, "Long-term behaviour of simply-supported steel-bars truss slabs recycled coarse aggregate," Constr. Build. Mater., vol. 116, pp. 335-346, 2016, http://dx.doi.org/10.1016/j.conbuildmat.2016.04.150.

Author contributions: LAMO: conceptualization, data curation, formal analysis, investigation, methodology, validation, writing-original draft; TMB: conceptualization, formal analysis, visualization, writing-review \& editing; YOR: data curation, investigation, validation, writing-review \& editing; ALHCE: conceptualization, resources, supervision, visualization, writing-review \& editing.

Editors: Samir Maghous, Guilherme Aris Parsekian. 